\title{
Article
}

\section{Improvement of Damage in Human Dermal Fibroblasts by 3,5,7-Trimethoxyflavone from Black Ginger (Kaempferia parviflora)}

\author{
Sullim Lee ${ }^{1} \mathbb{D}$, Taesu Jang ${ }^{2}$, Ki Hyun Kim ${ }^{3, * \mathbb{D}}$ and Ki Sung Kang ${ }^{4, *}$ \\ 1 Department of Life Science, College of Bio-Nano Technology, Gachon University, Seongnam 13120, Korea; \\ sullimlee@gachon.ac.kr \\ 2 College of Medicine, Dankook University, Cheonan 31116, Korea; jangts@dankook.ac.kr \\ 3 School of Pharmacy, Sungkyunkwan University, Suwon 16419, Korea \\ 4 College of Korean Medicine, Gachon University, Seongnam 13120, Korea \\ * Correspondence: khkim83@skku.edu (K.H.K.); kkang@gachon.ac.kr (K.S.K.); \\ Tel.: 82-31-290-7700 (K.H.K.); 82-31-750-5402 (K.S.K.); Fax: 82-31-750-5416 (K.S.K.)
}

Citation: Lee, S.; Jang, T.; Kim, K.H.; Kang, K.S. Improvement of Damage in Human Dermal Fibroblasts by 3,5,7-Trimethoxyflavone from Black Ginger (Kaempferia parviflora).

Antioxidants 2022, 11, 425. https:// doi.org/10.3390/antiox11020425

Academic Editor: Salvador Máñez Aliño

Received: 21 December 2021 Accepted: 17 February 2022 Published: 19 February 2022

Publisher's Note: MDPI stays neutral with regard to jurisdictional claims in published maps and institutional affiliations.

Copyright: (C) 2022 by the authors. Licensee MDPI, Basel, Switzerland. This article is an open access article distributed under the terms and conditions of the Creative Commons Attribution (CC BY) license (https:// creativecommons.org/licenses/by/ $4.0 /)$.

\begin{abstract}
Reactive oxygen species (ROS) are generated during intrinsic (chronological aging) and extrinsic (photoaging) skin aging. Therefore, antioxidants that inhibit ROS production may be involved in delaying skin aging. In this study, we investigated the potential effects of compounds isolated from black ginger, Kaempferia parviflora, a traditional medicinal plant, on normal human dermal fibroblasts in the context of inflammation and oxidative stress. The isolated compounds were structurally characterized as 5-hydroxy-7-methoxyflavone (1), 3,7-dimethoxy-5-hydroxyflavone (2), 5-hydroxy-3,7,3,4-tetramethoxyflavone (3), 7,4-dimethylapigenin (4), 3,7,4-trimethylkaempferol (5), and 3,5,7-trimethoxyflavone (6), using nuclear magnetic resonance spectroscopy (NMR) and liquid chromatography-mass spectrometry (LC/MS) analyses. These flavonoids were first evaluated for their ability to suppress extracellular matrix degradation in normal human dermal fibroblasts. Of these, 3,5,7-trimethoxyflavone (6) significantly inhibited the tumor necrosis factor (TNF)- $\alpha$-induced high expression and secretion of matrix metalloproteinase (MMP)- 1 by cells. We further found that 3,5,7-trimethoxyflavone suppressed the excessive increase in ROS, mitogen-activated protein kinases (MAPKs), Akt, and cyclooxygenase-2 (COX-2)and increased heme oxygenase (HO)-1 expression. The expression of pro-inflammatory cytokines, including interleukin (IL)-1 $\beta$, IL-6, and IL-8, was also suppressed by 3,5,7-trimethoxyflavone (6). Taken together, our results indicate that 3,5,7trimethoxyflavone (6) isolated from K. parviflora is a potential candidate for ameliorating skin damage.
\end{abstract}

Keywords: human dermal fibroblasts; tumor necrosis factor- $\alpha$; Kaempferia parviflora; 3,5,7trimethoxyflavone; improvement of skin damage

\section{Introduction}

The skin is a major defensive organ formed from the human ectoderm; it performs sensory, control, and protective functions when in direct contact with latent harmful factors [1]. Intrinsic aging appears with a gradual decrease in cell activity of skin with age, and is caused by reactive oxygen species (ROS) produced from the cell metabolic process [2,3]. External aging and skin damage occur upon direct exposure to the external environment and are caused by environmental hazards, such as pollution, chemicals, smoking, and ultraviolet (UV) radiation [4,5]. UV radiation substantially contributes to various skin injuries and diseases, including skin aging and inflammatory skin diseases [6,7]. UV radiation induces intracellular ROS formation, causing widespread inflammatory damage from the epidermis to the dermis, resulting in accumulative skin damage, such as skin pigmentation and photoaging [8,9]. ROS generation causes intracellular oxidative damage and changes, 
such as DNA denaturation, cell membrane destruction, and inflammatory responses, causing functional problems [10-12]. Harmful alien substances can cause accumulation of ROS, which are produced by oxidative phosphorylation in the mitochondria [13]. Excessive ROS in the skin induces wrinkle formation because of cleavage of elastic fibers and fibrous proteins, such as collagen, which comprise the skin extracellular matrix (ECM) [6]. Matrix metalloproteinase-1 (MMP-1) is a collagenase that degrades collagen [14]. The major cause of extrinsic aging is a complex reaction induced by ROS, which is produced by the absorption of ultraviolet light by the skin. [15]. Therefore, substances that inhibit ROS and MMP-1 production can be effective in preventing skin damage, such as skin aging.

When the skin is exposed to UV light, inducible nitric oxide synthase (iNOS), cyclooxygenase-2 (COX-2), tumor necrosis factor- $\alpha$ (TNF- $\alpha$ ), and interleukins (ILs) are directly or indirectly induced [16-18]. In particular, skin fibroblast damage caused by the inflammatory responses accelerates photoaging $[16,19]$. The hypersecretion of TNF- $\alpha$ increased by UV B stimulates immune cells to promote the production of collagenase, which leads to ECM breakdown and skin aging such as wrinkles. Suppression of collagen production and induction of collagen degradation results in negative changes, such as loss of elasticity and wrinkles [20]. Further, long-term exposure to ultraviolet rays makes inflammation chronic, which causes diverse skin diseases. Therefore, many previous studies have examined skin wrinkle improvement, focusing on collagenase inhibition [21-23].

The inflammatory cytokine TNF- $\alpha$, secreted by keratinocytes and UV irradiated fibroblasts, plays an important role in mediating skin aging as well as inflammatory diseases. With respect to skin aging, TNF- $\alpha$ suppresses collagen biosynthesis in skin fibroblasts and regulates collagen production through various signaling pathways [24]. Further, TNF- $\alpha$ induces the production of MMP interstitial collagenase (MMP-1) and the breakdown of collagen fibers [24,25]. Therefore, TNF- $\alpha$ activity regulation can be a powerful approach for developing new treatments for preventing inflammation related skin diseases and aging.

$K$. parviflora, also known as Thai ginseng or black ginger, is a medicinal plant belonging to the family Zingiberaceae. K. parviflora, known as Krachaidum in Thailand, is native to northern and northeastern Thailand. Its rhizomes are popular as a commercial health-promoting herb, and it has been used in traditional medicine to treat various diseases, including ulcers, inflammation, gout, allergy, abscesses, and osteoarthritis [26,27]. A number of previous pharmacological studies on the rhizome of K. parviflora have revealed its valuable therapeutic effects, including antimicrobial, anti-inflammatory, antiallergic, antioxidative, sex-enhancing, neuroprotective, vascular relaxation, anticancer, and cardioprotective activities [28]. Due to the pharmacological properties of its rhizomes, $K$. parviflora has been thoroughly investigated for its bioactive phytochemicals $[29,30]$, and methoxyflavones have been identified as the primary bioactive constituents in K. parviflora. A representative compound in $K$. parviflora rhizomes, 5,7,3', $4^{\prime}$-tetramethoxyflavone, exhibits diverse pharmacological properties [31,32]. The $\beta$-catenin and EP/cAMP/PKA signaling pathways were significantly inhibited by $5,7,3^{\prime}, 4^{\prime}$-tetramethoxyflavone in cultured rat chondrocytes, leading to articular cartilage and chondrocyte protection [31]. In addition, 5,7,3', $4^{\prime}$-tetramethoxyflavone exerted antiplasmodial effects against Plasmodium falciparum, with $\mathrm{IC}_{50}$ values of $3.70 \mu \mathrm{g} / \mathrm{mL}$ [32]. In this context, diverse bioactive compounds from K. parviflora have been attractive to natural product chemists for the discovery of novel bioactive agents.

As part of a continuing study for discovering bioactive natural products from natural resources [33-36], we explored potential bioactive flavonoids from K. parviflora, a traditional medicinal plant, because the antioxidant activity of such flavonoids can suppress intracellular oxidative damage and prevent oxidative stress-related damage to the skin ECM [37,38]. In this study, we separated methoxyflavones from a methanol extract of K. parviflora rhizomes using column chromatography and high-performance liquid chromatography (HPLC) under the guidance of liquid chromatography-mass spectrometry (LC-MS)-based analysis. We further examined their protective effects against TNF- $\alpha$ - 
induced aging damage to normal human dermal fibroblasts (NHDFs) and assessed the mechanism of action of these compounds.

\section{Materials and Methods}

\subsection{Plant Material}

K. parviflora rhizomes were collected in January 2020 from Chiang Mai City, northern Thailand. This material was authenticated by K. H. Kim. A voucher specimen (SKKU-BG 1908) was stored in the herbarium of the School of Pharmacy, Sungkyunkwan University, Suwon, Korea.

\subsection{Extraction of K. parviflora Rhizomes and Separation/Isolation of Compounds}

Dried K. parviflora rhizomes (132 g) were crushed and then extracted with $80 \%$ $\mathrm{MeOH} / \mathrm{H}_{2} \mathrm{O}(2.0 \mathrm{~L}, 24 \mathrm{~h} \times 2)$ at room temperature, and then the residue of $K$. parviflora rhizomes were extracted with $80 \% \mathrm{MeOH} / \mathrm{H}_{2} \mathrm{O}(3.0 \mathrm{~L}, 12 \mathrm{~h})$ under reflux. The filtered extracts were extracted at $20 \pm 5{ }^{\circ} \mathrm{C}$, were combined under reflux, and then evaporated under reduced pressure to obtain a crude $\mathrm{MeOH}$ extract $(9.2 \mathrm{~g})$ using a rotary evaporator. The resultant extract was applied to suspension using $700 \mathrm{~mL}$ of distilled water, and the suspended extract was solvent-partitioned by employing four organic solvents (each $700 \mathrm{~mL}$ ), specifically hexane, dichloromethane $\left(\mathrm{CH}_{2} \mathrm{Cl}_{2}\right)$, ethyl acetate (EtOAc), and $n$-butanol $(\mathrm{BuOH})$, three times. As a result, four fractions, the hexane-soluble $(1.0 \mathrm{~g})$, $\mathrm{CH}_{2} \mathrm{Cl}_{2}$-soluble (3.2 g), EtOAc-soluble (0.4 g), and $n$-BuOH-soluble $(0.5 \mathrm{~g})$ fractions were obtained. LC-MS analysis of each fraction was carried out on an Agilent 1200 Series HPLC equipment (Agilent Technologies, Santa Clara, CA, USA), furnished with a diode array detector (DAD) and 6130 Series ESI mass spectrometer, using an analytical Kinetex C18 $100 \AA$ Å column (Phenomenex, Torrance, CA, USA, $100 \times 2.1 \mathrm{~mm}, 5 \mu \mathrm{m}$ ) at flow rate of $0.3 \mathrm{~mL} / \mathrm{min}$. Based on the reference to a house-built UV library database, LC-MS analysis of the four fractions revealed the presence of the majority of flavonoids in the hexane-soluble fraction. Thin-layer chromatography was performed to detect the spots of compounds using precoated silica gel $\mathrm{F}_{254}$ plates and RP- $\mathrm{C}_{18} \mathrm{~F}_{254 \mathrm{~s}}$ plates (Merck, Darmstadt, Germany). The hexane-soluble fraction (1.0 g) was subjected to silica gel column chromatography (eluted with $n$-hexane/EtOAc [10:1 $\rightarrow 1: 1], \mathrm{CH}_{2} \mathrm{Cl}_{2} / \mathrm{MeOH}$ [10:1 $\left.\rightarrow 1: 1\right]$, gradient solvent system) to obtain six fractions (H1-H6). Fraction $\mathrm{H} 2(91.5 \mathrm{mg}$ ) was separated by Sephadex LH-20 column chromatography $\left.\left(\mathrm{CH}_{2} \mathrm{Cl}_{2} / \mathrm{MeOH} 2: 8\right]\right)$ to obtain five subfractions ( $\mathrm{H} 21-$ $\mathrm{H} 25)$. Subfraction $\mathrm{H} 22(29.2 \mathrm{mg}$ ) was isolated using semi-preparative reverse-phase HPLC with $78 \% \mathrm{MeOH} / \mathrm{H}_{2} \mathrm{O}$ (flow rate of $2 \mathrm{~mL} / \mathrm{min}$ ) to obtain compounds $1(1.5 \mathrm{mg}$ ) and 2 $(2.4 \mathrm{mg})$. Fraction H5 (112.7 mg) was subjected to Sephadex LH-20 column chromatography $\left[\mathrm{CH}_{2} \mathrm{Cl}_{2} / \mathrm{MeOH}(2: 8)\right]$ to obtain two subfractions (H51 and H52). Subfraction H52 (28.2 mg) was separated using semi-preparative reverse-phase HPLC with $83 \% \mathrm{MeOH} / \mathrm{H}_{2} \mathrm{O}$ (flow rate of $2 \mathrm{~mL} / \mathrm{min})$ to isolate compounds $3(2.2 \mathrm{mg}), 4(2.5 \mathrm{mg})$, and $5(0.5 \mathrm{mg})$. Finally, fraction $\mathrm{H6}(271.8 \mathrm{mg})$ was fractionated by Sephadex LH-20 column chromatography $\left(\mathrm{CH}_{2} \mathrm{Cl}_{2} / \mathrm{MeOH}\right.$ [2:8]) to obtain four subfractions (H61-H64). Subfraction H64 (46.3 mg) was isolated using semi-preparative reverse-phase $\mathrm{HPLC}$ with $78 \% \mathrm{MeOH} / \mathrm{H}_{2} \mathrm{O}$ (flow rate of $2 \mathrm{~mL} / \mathrm{min}$ ) to obtain compound $6(3.0 \mathrm{mg})$.

\subsection{Cell Culture and Sample Preparations}

We purchased NHDFs from PromoCell GmbH (Heidelberg, Germany). Cells were maintained in Dulbecco's modified Eagle medium (Corning, Manassas, VA, USA). The medium consisted of $10 \%$ fetal bovine serum (Atlas, Fort Collins, CO, USA) and $100 \mathrm{U} / \mathrm{mL}$ penicillin-streptomycin solution (Gibco, Grand Island, NY, USA). Cells were cultured in a humid atmosphere containing $5 \% \mathrm{CO}_{2}$ at $37^{\circ} \mathrm{C}$. The six isolated compounds for cell treatment were prepared by dissolving them in dimethyl sulfoxide (DMSO; Sigma-Aldrich, St. Louis, MO, USA), and the final concentration was kept below $0.1 \%$. TNF- $\alpha$ (PeproTech, Rocky Hill, NJ, USA) was prepared by dissolving in $1 \%$ bovine serum albumin. 


\subsection{Cell Viability}

We seeded NHDFs at $1 \times 10^{4}$ cells/well in 96-well plates and incubated them for $24 \mathrm{~h}$. To create starvation conditions, the medium was then exchanged for serum-free. Serum starvation drives all cells to a phase of growth arrest, making all cells have the same cell cycle [39]. After $24 \mathrm{~h}$, the NHDFs were exposed to each concentration of the compound. After $24 \mathrm{~h}$, to measure cell viability, EZ-Cytox solution (Dogen, Seoul, Korea) was added to each cell-containing well, and absorbance was then determined after incubation for $2 \mathrm{~h}$. The measurement was performed using a SPARK 10M device (Tecan Group Ltd., Männedorf, Switzerland), and the wavelength was set to $450 / 600 \mathrm{~nm}$. Cell viability for each sample was presented as percent of the vehicle control.

\subsection{Evaluation of Intracellular ROS}

We seeded NHDFs at $1 \times 10^{4}$ cells/well in 96-well black plates, incubated them for $24 \mathrm{~h}$, and then replaced the medium with serum-free medium to create starvation conditions. After $24 \mathrm{~h}$, cells were treated with 3,5,7-trimethoxyflavone for $24 \mathrm{~h}$. The cells were then exposed to $20 \mathrm{ng} / \mathrm{mL}$ TNF- $\alpha$ (PeproTech, Rocky Hill, NJ, USA) for $15 \mathrm{~min}$. After $15 \mathrm{~min}$ of incubation, staining was carried out with dichlorofluorescein diacetate (DCFDA; SigmaAldrich) and washed with phosphate-buffered saline (Welgene, Gyeongsangbuk, Korea). Fluorescence imaging was performed using a fluorescence microscope IX51 (Olympus, Tokyo, Japan). Fluorescence was measured using a SPARK 10M, and the wavelength was set to $485 / 535 \mathrm{~nm}$. Results of intracellular ROS were presented as percent of the vehicle control.

\subsection{Real-Time Quantitative Reverse Transcription PCR}

We seeded NHDFs at $3 \times 10^{5}$ cells/well in 6-well plates, incubated them for $24 \mathrm{~h}$, and then replaced the medium with a serum-free medium to create starvation conditions. After $24 \mathrm{~h}$, cells were treated with 3,5,7-trimethoxyflavone for $24 \mathrm{~h}$. The cells were then exposed to $20 \mathrm{ng} / \mathrm{mL}$ TNF- $\alpha$ for $15 \mathrm{~min}$. To measure expression of IL-1 $\beta$, IL-6, IL-8, and $\beta$-actin, the cells were harvested after $4 \mathrm{~h}$. To test for MMP- 1 and procollagen I $\alpha 1$ (COLIA1), the cells were harvested after $24 \mathrm{~h}$. Next, the cells were harvested and isolated to cellular RNA by a RNeasy Mini Kit (QIAGEN, Hilden, Germany). Complementary DNA synthesis was performed using the RevertAid First Strand cDNA Synthesis Kit (Thermo Fisher Scientific, Waltham, MA, USA). Real-time PCR was carried out using PowerUp SYBR PCR Master Mix (Applied Biosystems, Waltham, MA, USA). The reaction was performed using the QuantStudio $^{\mathrm{TM}} 3$ Real-Time PCR System (Applied Biosystems), and the thermal conditions were set to 40 cycles $\left(95^{\circ} \mathrm{C}\right.$ for $15 \mathrm{~s}, 60^{\circ} \mathrm{C}$ for $30 \mathrm{~s}, 95^{\circ} \mathrm{C}$ for $\left.30 \mathrm{~s}\right)$. The primer sequences are shown in a previous paper [40], and $\beta$-actin was used as the reference gene.

\subsection{Enzyme-Linked Immunosorbent Assay (ELISA)}

We seeded NHDFs at $2 \times 10^{4}$ cells / well in 48-well plates, incubated them for $24 \mathrm{~h}$, and then replaced the medium with a serum-free medium to create starvation conditions. After $24 \mathrm{~h}$, the NHDF was treated with 3,5,7-trimethoxyflavone for $1 \mathrm{~h}$, followed by exposure to $20 \mathrm{ng} / \mathrm{mL}$ of TNF- $\alpha$. To measure protein expression for IL- $1 \beta$, IL- 6 , and IL-8, the medium was collected from cells after $12 \mathrm{~h}$. To measure protein expression for MMP-1 and procollagen I $\alpha 1$ (COLIA1), the medium was collected from cells after $24 \mathrm{~h}$. Protein secretion was determined using a human Total MMP-1 DuoSet ELISA kit and a Human ProCollagen I alpha 1 DuoSet ELISA (R\&D systems, Minneapolis, MN, USA). The absorbance was measured using a SPARK 10M spectrophotometer, and the wavelength was set to $550 / 600 \mathrm{~nm}$. Results of protein secretion were presented as percent of the vehicle control. 


\subsection{Western Blotting}

We seeded NHDFs at $3 \times 10^{5}$ cells/well in 6-well plates, incubated them for $24 \mathrm{~h}$, and then replaced the medium with a serum-free medium to create starvation conditions. After $24 \mathrm{~h}$, cells were treated with 3,5,7-trimethoxyflavone for $24 \mathrm{~h}$. The cells were then exposed to $20 \mathrm{ng} / \mathrm{mL}$ TNF- $\alpha$. To test for phospho-ERK, ERK, phospho-p38, p38, phospho-JNK, JNK, and GAPDH, the cells were collected after $15 \mathrm{~min}$. To test for phospho-Akt, Akt, COX-2, heme oxygenase 1 (HO-1), and GAPDH, the cells were collected after $6 \mathrm{~h}$. The cells were lysed with $1 \times$ radioimmunoprecipitation assay (RIPA) buffer (Tech \& Innovation, Gangwon, Korea). The lysate was centrifuged, and the supernatant was prepared as eluted protein samples. The protein concentration was determined using a BCA Protein Assay Kit (Merck). Equal protein levels were analyzed using Western blotting. The primary antibodies, phospho-ERK, ERK, phospho-p38, p38, phospho-JNK, JNK, phospho-Akt, Akt, COX-2, HO-1, COX-2, and GAPDH (Cell Signaling Technology, Danvers, MA, USA) were reacted for $4 \mathrm{~h}$ at $20 \pm 5{ }^{\circ} \mathrm{C}$. The secondary antibodies, goat anti-rabbit IgG-HRP, and goat anti-mouse IgG-HRP (Santa Cruz Biotechnology, Dallas, TX, USA), were incubated for $1 \mathrm{~h}$ at room temperature. Protein bands were visualized using SuperSignal ${ }^{\circledR}$ West Femto Maximum Sensitivity Chemiluminescent Substrate (Thermo Fisher Scientific) and Fusion Solo Chemiluminescence System (PEQLAB Biotechnologie GmbH, Erlangen, Germany). The band densities were calculated based on the ratio to the GAPDH band. Results were calculated from band density and were presented as percent of vehicle control.

\subsection{Statistical Analysis}

The experimental data are presented as mean \pm standard error of the mean (SEM). Differences of each group were assessed by using one-way analysis of variance (ANOVA) followed by Tukey's HSD (honestly significant difference) test. A $p$-value of 0.05 or less was considered statistically significant.

\section{Results}

\subsection{Isolation and Structural Identification of Compounds}

The $\mathrm{MeOH}$ extract of $\mathrm{K}$. parviflora rhizomes was sequentially subjected to solvent partitioning by employing four organic solvents, specifically hexane, $\mathrm{CH}_{2} \mathrm{Cl}_{2}, \mathrm{EtOAc}$, and $n-\mathrm{BuOH}$, to yield four fractions. As a result of LC-MS analysis of each fraction, it was confirmed that the hexane fraction had the highest content of flavonoids with antioxidant potential. Six methoxyflavones (1-6; Figure 1) were isolated from the hexane fraction using repeated column chromatography and semi-preparative HPLC separation. These isolated methoxyflavones were structurally characterized as 5-hydroxy7-methoxyflavone (1) [41], 3,7-dimethoxy-5-hydroxyflavone (2) [42], 5-hydroxy-3,7,3' ,4'tetramethoxyflavone (3) [43], 7,4'-dimethylapigenin (4) [41], 3,7,4'-trimethylkaempferol (5) [44], and 3,5,7-trimethoxyflavone (6) [45] by comparing their nuclear magnetic resonance spectroscopic data (Figures S1-S6) with those previously reported as well as MS data obtained from LC-MS analyses.

\subsection{Effect of Flavonoids 1-6 Isolated from K. parviflora on Viability of NHDFs}

Ahead of investigating the anti-aging effects of flavonoids 1-6 isolated from K. parviflora, their effects on NHDF cell viability were measured. As shown in Figure 2, flavonoids 1-6 did not exhibit considerable cytotoxicity against NHDFs at $100 \mu \mathrm{M}$. Therefore, all flavonoids were used in subsequent experiments at concentrations up to $100 \mu \mathrm{M}$. 
(a)

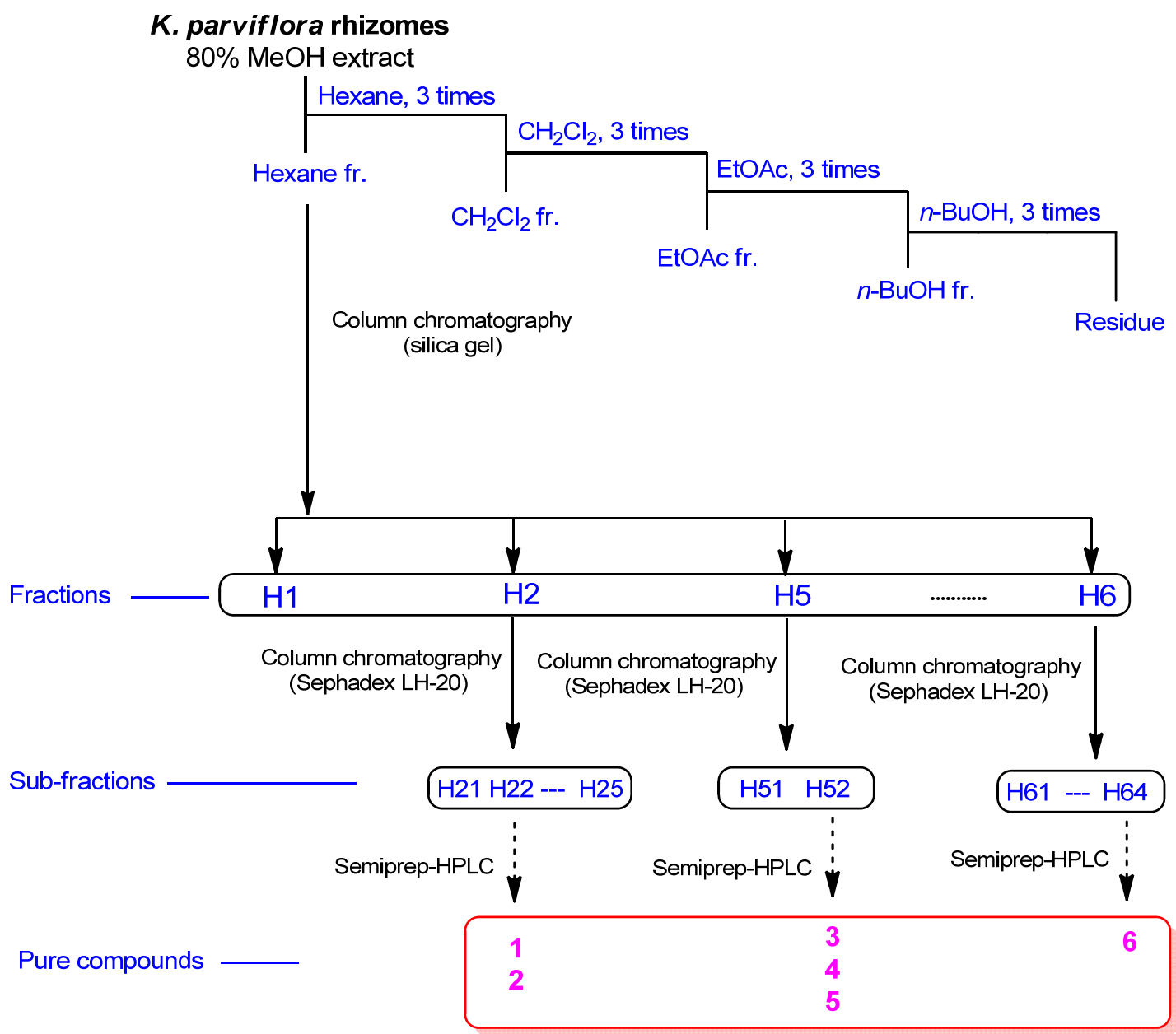

(b)<smiles>COc1cc(O)c2c(=O)cc(-c3ccccc3)oc2c1</smiles>

1<smiles>COc1cc(O)c2c(=O)c(OC)c(-c3ccccc3)oc2c1</smiles>

2<smiles>COc1cc(O)c2c(=O)c(OC)c(-c3ccc(OC)c(OC)c3)oc2c1</smiles>

3<smiles>COc1ccc(-c2cc(=O)c3c(O)cc(OC)cc3o2)cc1</smiles>

4<smiles>COc1ccc(-c2oc3cc(OC)cc(O)c3c(=O)c2OC)cc1</smiles>

5<smiles>COc1cc(OC)c2c(=O)c(OC)c(-c3ccccc3)oc2c1</smiles>

6

Figure 1. The separation scheme (a) and the chemical structures (b) of compounds 1-6. 

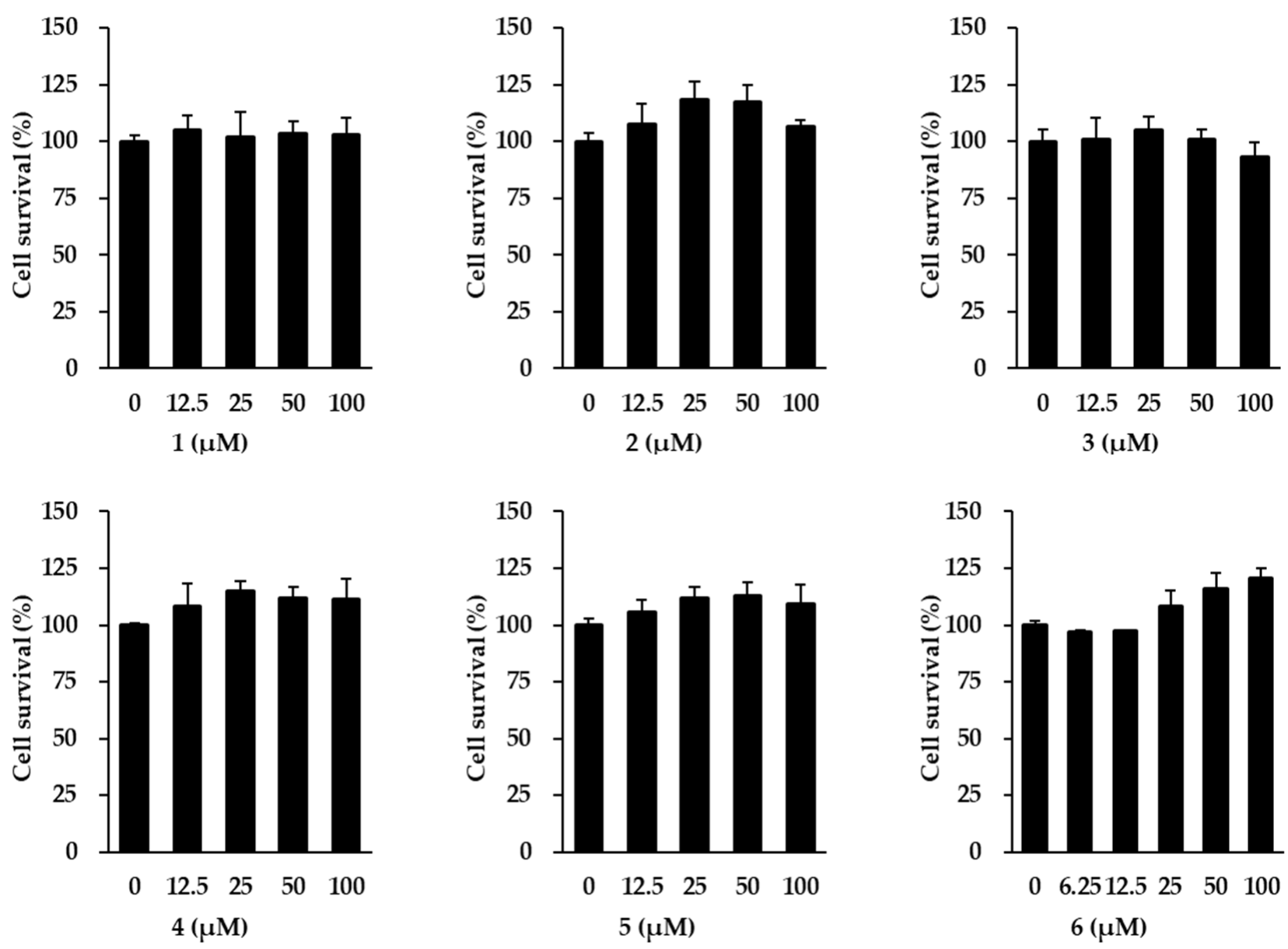

Figure 2. Survival of normal human dermal fibroblasts (NHDFs) under treatment with flavonoids 1-6 isolated from $K$. parviflora. We seeded NHDFs at $1 \times 10^{4}$ cells/well in 96-well plates, incubated them for $24 \mathrm{~h}$, and replaced the medium with a serum-free medium to create starvation conditions. After $24 \mathrm{~h}, \mathrm{NHDF}$ were exposed to each concentration of the compounds. After $24 \mathrm{~h}$, the measurement of cell viability was conducted with EZ-Cytox solution. Results of cell viability were presented as percent of the vehicle control. The results were obtained through three replicate experiments, and the graphs are represented as mean \pm SEM.

\subsection{Effect of Flavonoids Isolated from K. parviflora on MMP-1 Secretion in TNF- $\alpha$-Stimulated NHDFs}

We then investigated the inhibitory effects of the six flavonoids (1-6) by measuring the MMP-1 secretion by TNF- $\alpha$-stimulated NHDFs. As shown in Figure 3, TNF- $\alpha$ (20 ng/mL) significantly increased MMP-1 secretion by $3.37 \pm 0.08$-fold $(p<0.01)$ compared with that of the vehicle control. Among the six flavonoids from K. parviflora, 3,5,7trimethoxyflavone (6) potently reduced the secretion of MMP-1 induced by TNF- $\alpha$. Treatment with 50 and $100 \mu \mathrm{M} 6$ suppressed the secretion of MMP- 1 to $1.99 \pm 0.05$-fold $(p<0.01)$ and $1.76 \pm 0.06$-fold $(p<0.01)$, compared with that of the control. Therefore, we focused on 3,5,7-trimethoxyflavone in further studies to elucidate the mechanism by which it demonstrates protective effects against NHDF damage by TNF- $\alpha$. 

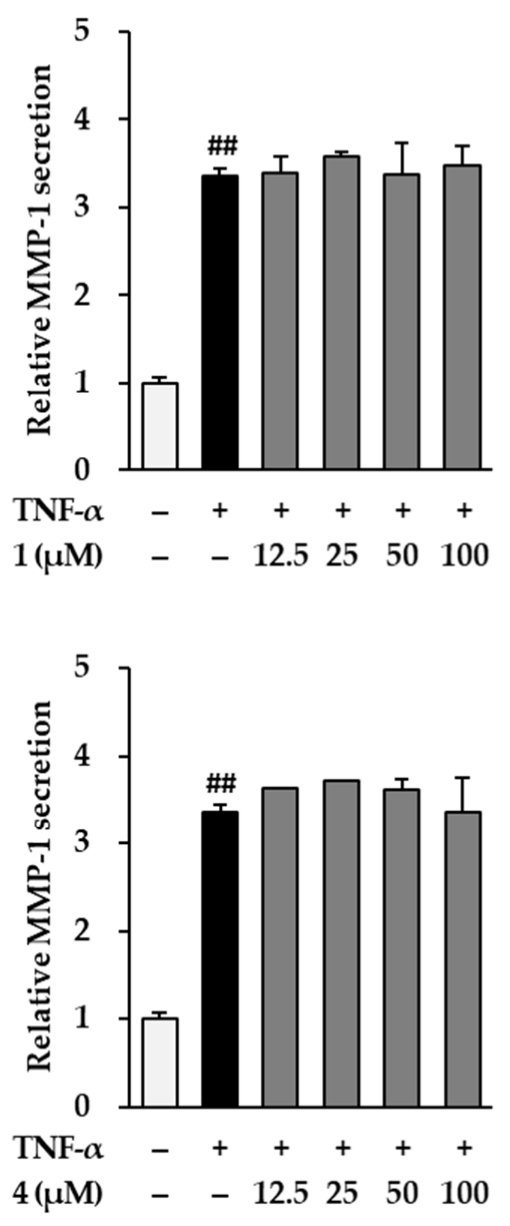
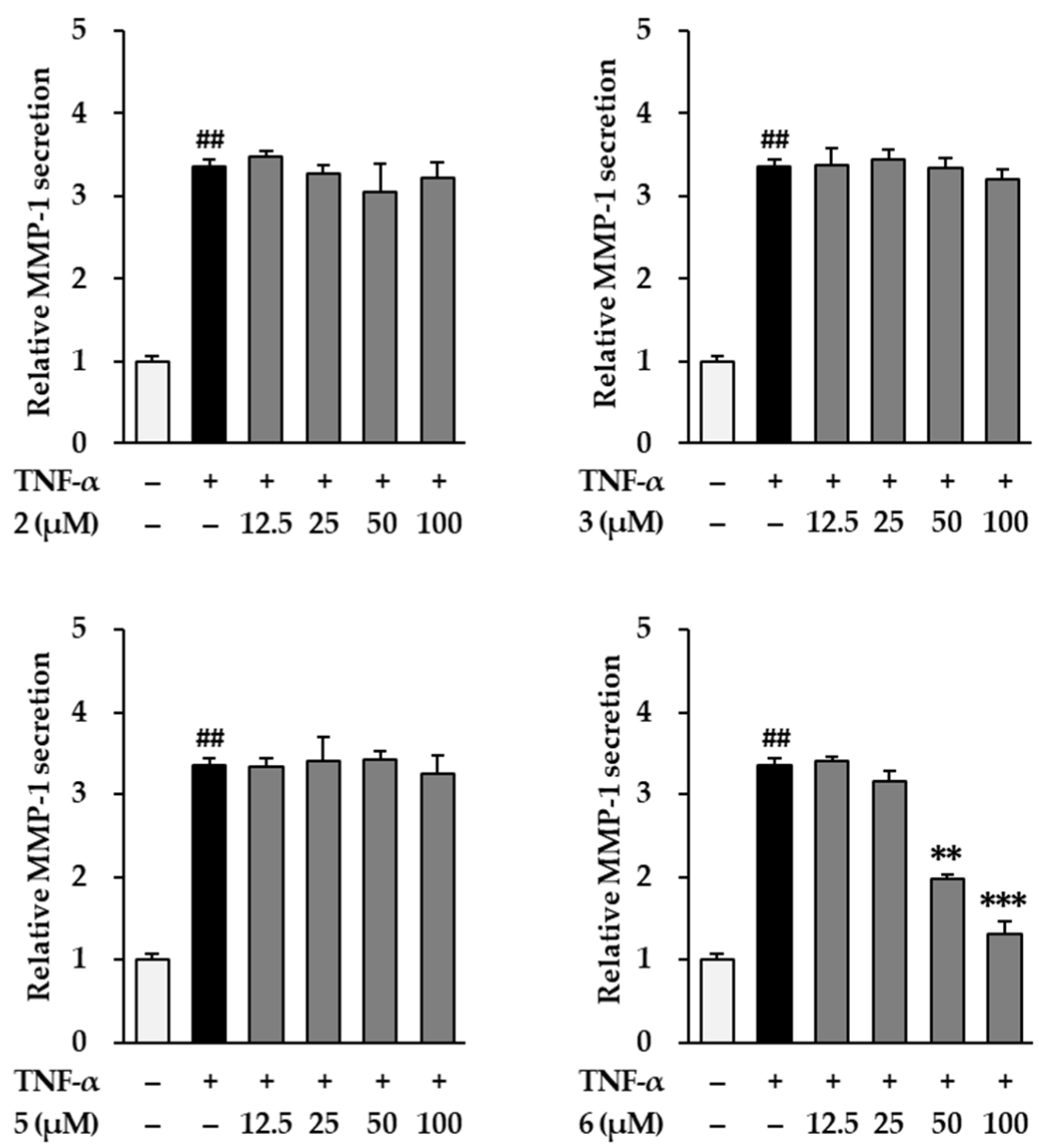

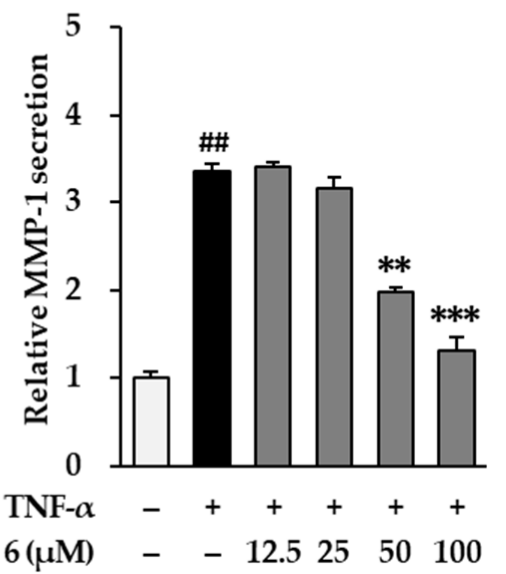

Figure 3. Effects of flavonoids 1-6 isolated from K. parviflora on MMP-1 secretion in normal human dermal fibroblasts (NHDFs). We seeded NHDFs at $2 \times 10^{4}$ cells/well in 48 -well plates, incubated them for $24 \mathrm{~h}$, and replaced the medium with a serum-free medium to create starvation conditions. After $24 \mathrm{~h}$, cells were treated with 50 and $100 \mu \mathrm{M}$ of 6 for $1 \mathrm{~h}$, and the cells were exposed to $20 \mathrm{ng} / \mathrm{mL}$ TNF- $\alpha$ for 24 h. After 24 h, we measured MMP-1 secretion with an ELISA kit. Results of MMP-1 secretion were presented as percent of the vehicle control. The results were obtained through three replicate experiments, and the graphs are represented as mean \pm SEM. ${ }^{\# \#} p<0.01$ vs. vehicle control. ** $p<0.01$ and ${ }^{* * *} p<0.001$ vs. TNF- $\alpha$ stimulated control.

\subsection{Effect of 3,5,7-Trimethoxyflavone on Intracellular ROS Accumulation in TNF- $\alpha$-Stimulated NHDFs}

TNF- $\alpha$ is a stimulator that can cause oxidative stress in NHDFs. Therefore, we evaluated the effect of 3,5,7-trimethoxyflavone on ROS accumulation in TNF- $\alpha$-stimulated NHDFs. As shown in the Figure 4, exposure of $20 \mathrm{ng} / \mathrm{mL}$ TNF- $\alpha$ did show dramatically increased ROS accumulation by $2.54 \pm 0.06$-fold $(p<0.05)$ compared with that in the vehicle control. In contrast, 3,5,7-trimethoxyflavone (6) significantly reduced ROS accumulation. Treatment with 50 and $100 \mu \mathrm{M} 6$ suppressed ROS production to $1.88 \pm 0.14$-fold $(p<0.05)$ and $1.33 \pm 0.09$-fold $(p<0.01)$, respectively, compared with that in the control.

\subsection{Effect of 3,5,7-Trimethoxyflavone on TNF- $\alpha$-Induced Phosphorylation of MAPKs in NHDFs}

To improve the understanding of the mechanism of the cytoprotective action of 3,5,7-trimethoxyflavone (6), we evaluated its effect on MAPK phosphorylation in TNF- $\alpha$ stimulated NHDFs. MAPK protein expression was analyzed using Western blotting. As shown in Figure 5, exposure of $20 \mathrm{ng} / \mathrm{mL}$ TNF- $\alpha$ did show activation by of ERK, JNK, and p38 in NHDFs, which was reduced upon treatment with 6. ERK phosphorylation by 
TNF- $\alpha$-stimulation was shown to increase by $2.72 \pm 0.35$-fold, whereas treatment with 6 suppressed ERK phosphorylation to $1.30 \pm 0.42$-fold $(50 \mu \mathrm{M})$ and $0.77 \pm 0.30$-fold $(100 \mu \mathrm{M}$, $p<0.05)$ compared with that in the control. JNK phosphorylation by TNF- $\alpha$-stimulation was shown to increase by $8.15 \pm 0.45$-fold, whereas treatment with 6 suppressed it by $4.88 \pm 0.24$-fold ( $50 \mu \mathrm{M}, p<0.05)$, and $4.86 \pm 0.13$-fold $(100 \mu \mathrm{M}, p<0.05)$ of the control. Further, TNF- $\alpha$ stimulation increased p38 phosphorylation by $6.43 \pm 0.17$-fold, whereas treatment with 6 suppressed it by $5.58 \pm 0.42$-fold $(50 \mu \mathrm{M})$, and $5.20 \pm 0.31$-fold $(100 \mu \mathrm{M})$ compared with the control; however, this difference was not significant. These results indicate that 3,5,7-trimethoxyflavone (6) can suppress the MAPK phosphorylation induced by $\mathrm{TNF}-\alpha$ stimulation.

(A)

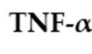

$6(\mu \mathrm{M})$
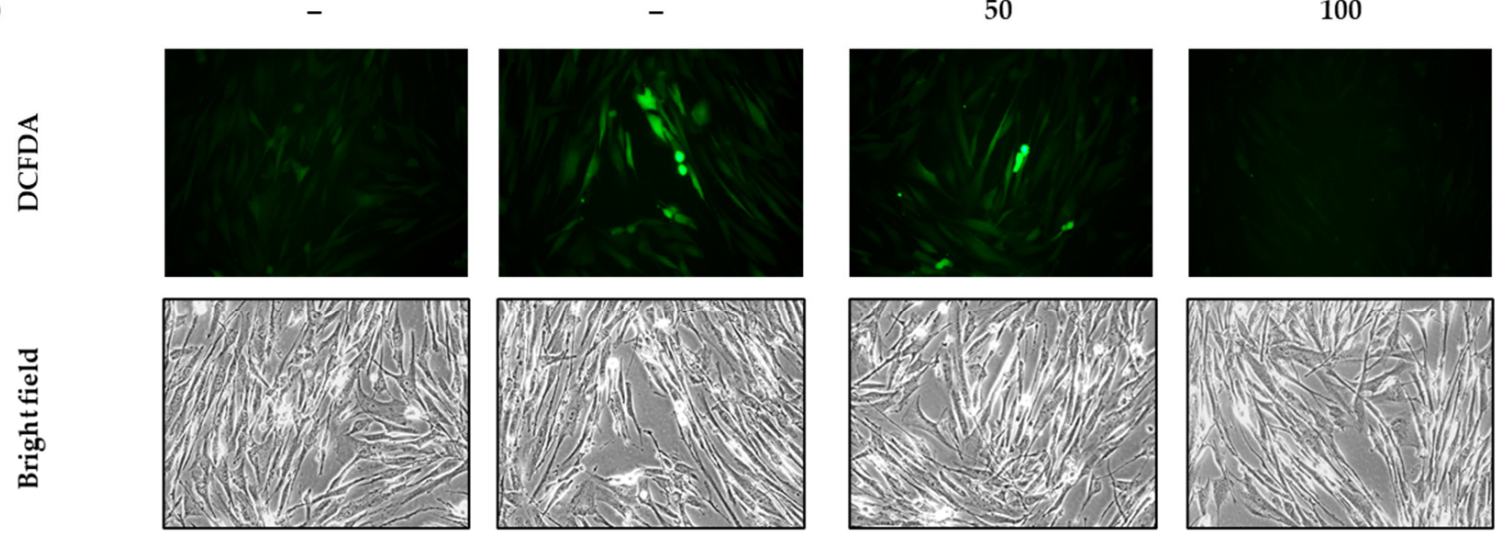

(B)

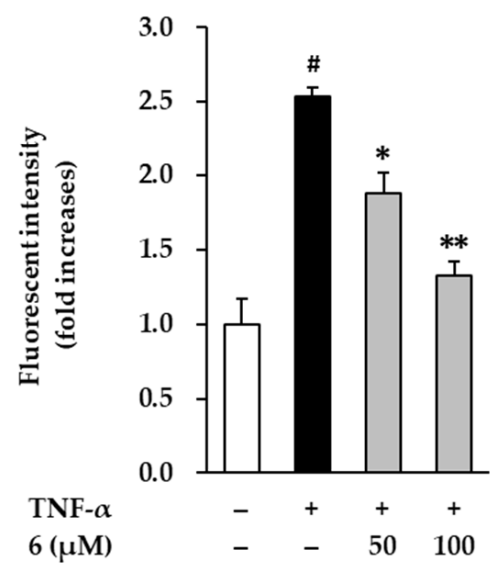

Figure 4. Effects of 3,5,7-trimethoxyflavone (6) on intracellular ROS accumulation in TNF- $\alpha$ stimulated normal human dermal fibroblasts (NHDFs). (A) Bands of protein expressions. (B) Bar graphs of the relative expression. We seeded NHDFs at $1 \times 10^{4}$ cells/well in 96-well black plates incubated them for $24 \mathrm{~h}$, and replaced the medium with a serum-free medium to create starvation conditions. After $24 \mathrm{~h}$, cells were treated with 50 and $100 \mu \mathrm{M}$ of 6 for $1 \mathrm{~h}$, and the cells were exposed to $20 \mathrm{ng} / \mathrm{mL}$ TNF- $\alpha$ for $15 \mathrm{~min}$. The cell was stained with dichlorofluorescin diacetate (DCFDA) for $15 \mathrm{~min}$, and photographs was observed with a microscope IX51. The measurement of fluorescence was conducted using a SPARK 10M. Results of intracellular ROS were presented as a percent of the vehicle control. The results were obtained through three replicate experiments, and the graphs are represented as mean \pm SEM. ${ }^{\#} p<0.05$ vs. vehicle control. ${ }^{*} p<0.05$ and ${ }^{* *} p<0.01$ vs. TNF- $\alpha$ stimulated control. 
(A)

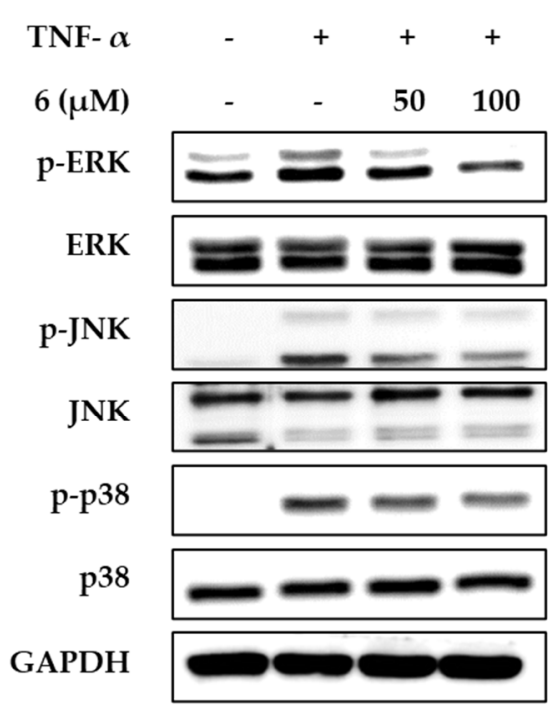

(B)
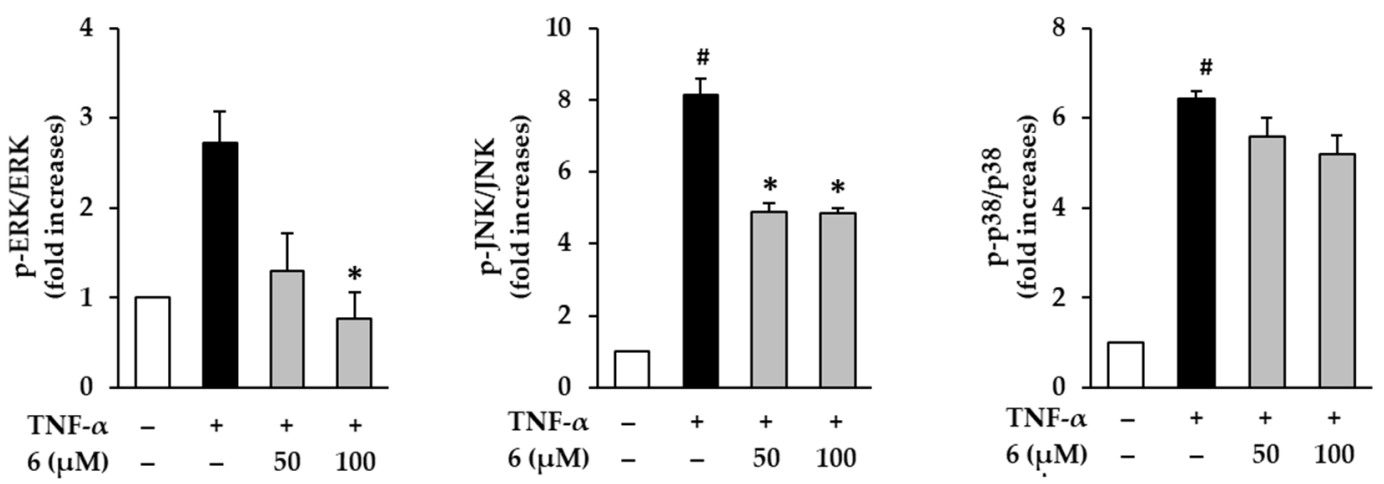

Figure 5. Effects of 3,5,7-trimethoxyflavone (6) on MAPK phosphorylation in normal human dermal fibroblasts (NHDFs) stimulated by TNF- $\alpha$. (A) Bands of protein expressions. (B) Bar graphs of the relative expression. NHDFs were seeded at a density of $3 \times 10^{5}$ cells/well in 6-well plates and incubated for $24 \mathrm{~h}$, and then the medium was replaced with a serum-free medium to create starvation conditions. After $24 \mathrm{~h}$, cells were treated with 50 and $100 \mu \mathrm{M}$ of 6 for $1 \mathrm{~h}$, and the cells were exposed to $20 \mathrm{ng} / \mathrm{mL}$ TNF- $\alpha$ for $15 \mathrm{~min}$. Relative comparison of expression levels of p-ERK, ERK, p-JNK, JNK, p-p38, p38, and GAPDH proteins were determined with Western blotting. Results of each protein expression was presented as percent of the vehicle control. The results were obtained through three replicate experiments, and the graphs are represented as mean \pm SEM. ${ }^{*} p<0.05$ vs. vehicle control. * $p<0.05$ vs. TNF- $\alpha$ stimulated control.

3.6. Effect of 3,5,7-Trimethoxyflavone on Akt Phosphorylation and Expression of COX-2 and HO-1 in TNF- $\alpha$-Stimulated NHDFs

Immoderate production of ROS activates Akt, which causes inflammation by upregulating COX-2 [46]. To determine the protective effect of 3,5,7-trimethoxyflavone (6) against the inflammatory response, we evaluated its effect on Akt phosphorylation and COX-2 expression in TNF- $\alpha$-stimulated NHDFs. Western blotting was used to measure protein expression levels of p-Akt, Akt, and COX-2. As shown in Figure 6, $20 \mathrm{ng} / \mathrm{mL}$ TNF- $\alpha$ exposure induced Akt phosphorylation in NHDFs compared to that with the vehicle control, which was reduced upon treatment with 6 . TNF- $\alpha$ stimulation increased Akt phosphorylation by $2.61 \pm 0.38$-fold, whereas treatment with 6 suppressed it by $1.13 \pm 0.28$-fold $(50 \mu \mathrm{M})$ and $0.90 \pm 0.12$-fold $(100 \mu \mathrm{M}, p<0.05)$ compared with that in the control. Further, TNF- $\alpha$ stimulation increased COX-2 expression by $5.85 \pm 0.11$-fold, whereas treatment with 6 suppressed it by $4.78 \pm 0.61$-fold $(50 \mu \mathrm{M})$ and $2.36 \pm 1.00$-fold $(100 \mu \mathrm{M})$ compared with that in the control; however, this difference was not significant. These results indicated that 3,5,7- 
trimethoxyflavone (6) suppressed the activation of inflammation by TNF- $\alpha$ stimulation. Therefore, 3,5,7-trimethoxyflavone has an ameliorating effect on the inflammation induced by ROS accumulation.

(A)

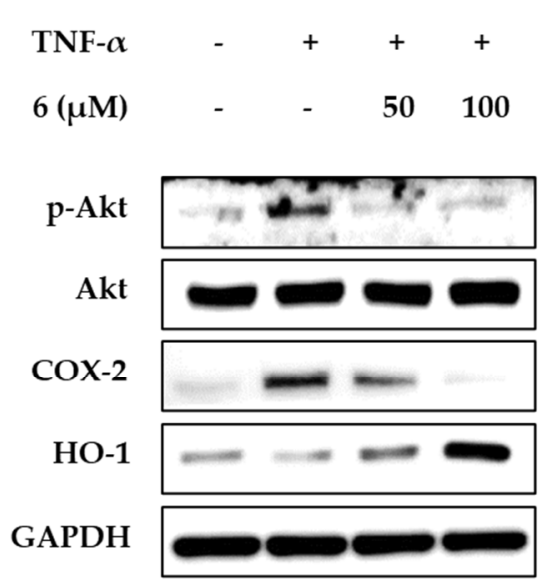

(B)
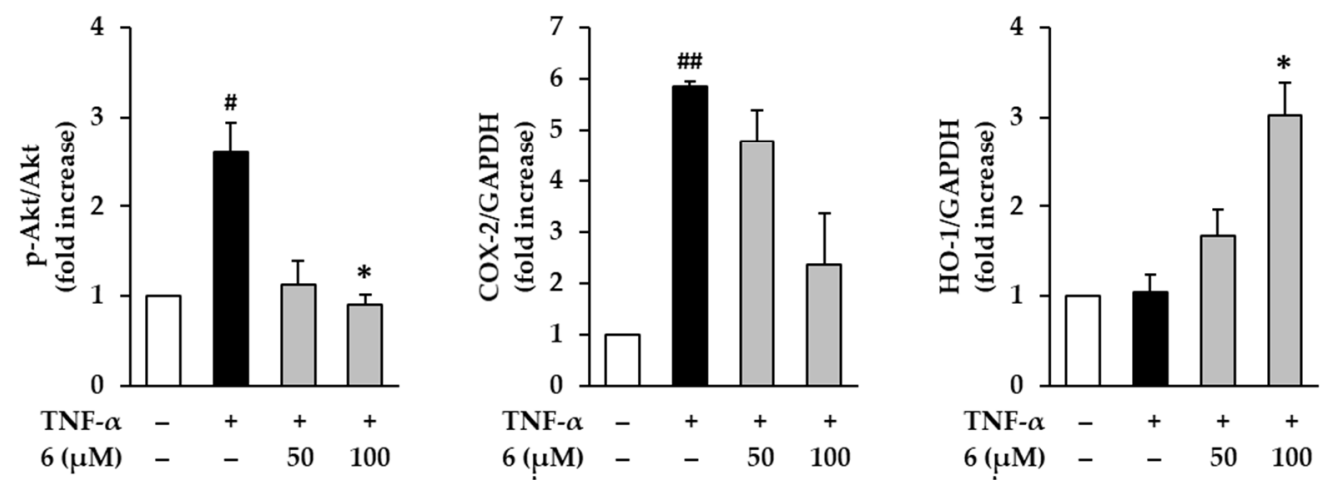

Figure 6. Effects of 3,5,7-trimethoxyflavone (6) on MAPK phosphorylation in TNF- $\alpha$ stimulated normal human dermal fibroblasts (NHDFs). (A) Bands of protein expressions. (B) Bar graphs of the relative expression. We seeded NHDFs at $3 \times 10^{5}$ cells/well in 6-well plates, incubated for $24 \mathrm{~h}$, and then replaced the medium with a serum-free medium to create starvation conditions. After $24 \mathrm{~h}$, cells were treated with 50 and $100 \mu \mathrm{M}$ of 6 for $1 \mathrm{~h}$, and the cells were exposed to $20 \mathrm{ng} / \mathrm{mL}$ TNF- $\alpha$ for $6 \mathrm{~h}$. Protein expressions of $\mathrm{p}-\mathrm{Akt}$, Akt, COX-2, HO-1, and GAPDH were determined with Western blotting. Results of each protein expression was presented as percent of the vehicle control. The results were obtained through three replicate experiments, and the graphs are represented as mean \pm SEM. ${ }^{\#} p<0.05$ and ${ }^{\# \#} p<0.01$ vs. vehicle control. ${ }^{*} p<0.05$ vs. TNF- $\alpha$ stimulated control.

An increase in HO-1 through the transcriptional activation of Nrf2 suppresses free radical production, thereby preventing inflammatory damage and apoptosis in human skin cells [47,48]. In Figure 6, exposure of $20 \mathrm{ng} / \mathrm{mL}$ TNF- $\alpha$ did not show alteration of HO-1 expression in NHDFs compared to that in the vehicle control; however, this was increased by treatment with 6 . HO-1 expression increased by $1.68 \pm 0.29$-fold $(50 \mu \mathrm{M})$ and $3.03 \pm 0.36$-fold $(100 \mu \mathrm{M}, p<0.05)$ of the control upon treatment with 6 . These results suggest that 3,5,7-trimethoxyflavone (6) inhibits the ROS accumulation induced by TNF- $\alpha$ stimulation through free radical trapping by $\mathrm{HO}-1$.

\subsection{Effect of 3,5,7-Trimethoxyflavone on MMP-1 and Pro-Collagen I $\alpha 1$ mRNA and Protein Expression in TNF- $\alpha$-Stimulated NHDFs}

UV radiation induces ROS accumulation, which alters the structure and function of genes and proteins, ultimately causing skin damage. It increases the expression and secretion of MMP-1 collagenase and induces collagen degradation. Eventually, the skin 
ECM disintegrates, leading to skin damage such as wrinkles $[49,50]$. Therefore, substances that inhibit collagenase activity are considered as potential therapeutic candidates for skin damage [51]. In Figure 7A, exposure of $20 \mathrm{ng} / \mathrm{mL}$ TNF- $\alpha$ did show increased MMP1 expression in NHDFs compared to that in the vehicle control; this was reduced by 3,5,7-trimethoxyflavone (6) treatment. TNF- $\alpha$ stimulation also increased MMP-1 mRNA expression by $3.76 \pm 0.03$-fold, whereas treatment with 6 suppressed it by $2.53 \pm 0.13$-fold $(50 \mu \mathrm{M})$ and $1.70 \pm 0.23$-fold $(100 \mu \mathrm{M}, p<0.05)$ compared with that in the control. As shown in Figure 3, MMP-1 secretion was induced by TNF- $\alpha$-stimulation, whereas treatment with 6 suppressed it. These results indicate that 3,5,7-trimethoxyflavone (6) inhibits MMP-1 expression induced by TNF- $\alpha$ stimulation.

(A)

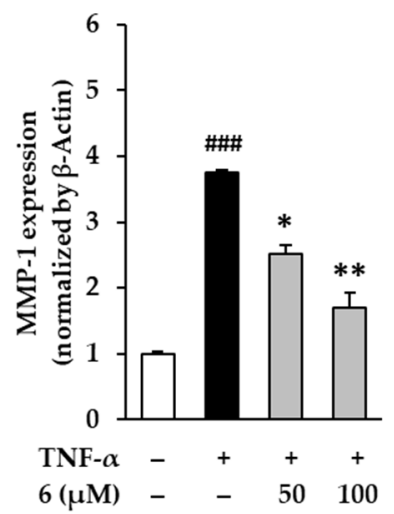

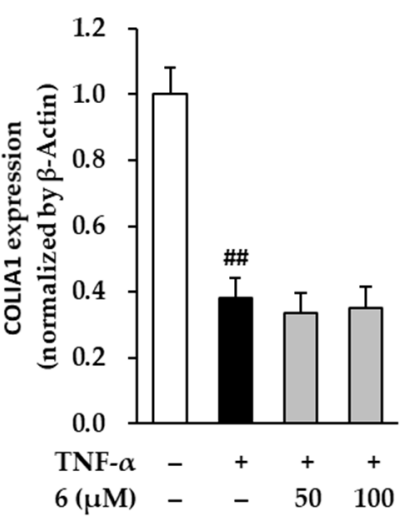

(B)

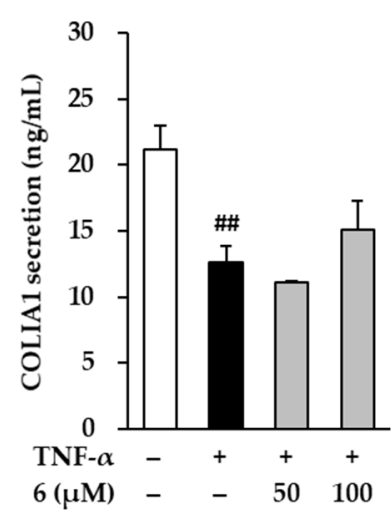

Figure 7. Effects of 3,5,7-trimethoxyflavone (6) on MMP-1 and COLIA1 in TNF- $\alpha$ stimulated normal human dermal fibroblasts (NHDFs). (A) The mRNA expressions of MMP-1 and COLIA1. We seeded NHDFs at $3 \times 10^{5}$ cells / well in 6-well plates, incubated them for $24 \mathrm{~h}$, and then replaced the medium with a serum-free medium to create starvation conditions. After $24 \mathrm{~h}$, cells were treated with 50 and $100 \mu \mathrm{M}$ of 6 for $1 \mathrm{~h}$, and the cells were exposed to $20 \mathrm{ng} / \mathrm{mL}$ TNF- $\alpha$ for $12 \mathrm{~h}$. The mRNA expressions of MMP-1 and COLIA1 were determined with RT-qPCR. Results of each mRNA expression was presented as percent of the vehicle control. (B) The protein secretion of COLIA1. We seeded NHDFs at or $2 \times 10^{4}$ cells /well in 48-well plates, incubated them for $24 \mathrm{~h}$, and then replaced the medium with a serum-free medium to create starvation conditions. After $24 \mathrm{~h}$, NHDFs were exposed to $20 \mathrm{ng} / \mathrm{mL}$ TNF- $\alpha$ in the presence or absence of 6 for $24 \mathrm{~h}$. The protein secretion of COLIA1 were determined with an ELISA kit. The results were obtained through three replicate experiments, and the graphs are represented as mean \pm SEM. ${ }^{\# \#} p<0.01$ and ${ }^{\# \# \#} p<0.001$ vs. vehicle control. ${ }^{*} p<0.05$ and ${ }^{* *} p<0.01$ vs. TNF- $\alpha$ stimulated control. 
Procollagen is secreted out of the cell, a part of the N-terminal peptide is cleaved by enzymes, and the cleaved procollagen is combined with the help of oxygen, iron ions, and ascorbic acid to form collagen in the form of fibers [52]. Therefore, the expression of procollagen COLIA1 was examined to indirectly evaluate collagen synthesis. In the Figure 7A, exposure of $20 \mathrm{ng} / \mathrm{mL}$ TNF- $\alpha$ did show a decrease in COLIA1 expression in NHDFs compared to that in the vehicle control. TNF- $\alpha$ stimulation decreased COL1A1 mRNA expression to $0.38 \pm 0.06$-fold, but this remained unchanged upon treatment with 3,5,7-trimethoxyflavone (6) at 50 and $100 \mu \mathrm{M}$. In Figure 7B, COLIA1 secretion induced by TNF- $\alpha$ stimulation decreased to $12.59 \pm 1.24 \mathrm{ng} / \mathrm{mL}$, compared with that in the vehicle control $(21.13 \pm 1.86 \mathrm{ng} / \mathrm{mL})$. Treatment with $100 \mu \mathrm{M}$ of 6 increased COLIA1 to $15.65 \pm 0.46 \mathrm{ng} / \mathrm{mL}$; however, this difference was not significant. Despite the lack of significance, this result indicated that 3,5,7-trimethoxyflavone (6) can reverse the decrease in COLIA1. In summary, these results suggest that 3,5,7-trimethoxyflavone (6) has the potential to suppress the advanced cutaneous ECM degradation induced by oxidative stress.

\subsection{Effect of 3,5,7-Trimethoxyflavone on Proinflammatory Cytokines in TNF- $\alpha$-Stimulated NHDFs}

When oxidative stress occurs, the response is hypersecretion of pro-inflammatory cytokines, including TNF- $\alpha$, IL-1 $\beta$, IL-6, and IL-8 [53]. Consequently, the inflammatory response is upregulated, leading to skin aging and various lesions [6,54]. To evaluate the effect of 3,5,7-trimethoxyflavone (6) on the inflammation-related responses in skin cells, IL-1 $\beta$, IL-6, and IL-8 levels were evaluated in TNF- $\alpha$-stimulated NHDFs.

In Figure $8 \mathrm{~A}$, exposure of $20 \mathrm{ng} / \mathrm{mL}$ TNF- $\alpha$ did show an increase in IL- $1 \beta$, IL6, and IL-8 in NHDFs compared to the vehicle control, which was reduced by 3,5,7trimethoxyflavone (6) treatment. IL-1 $\beta$ mRNA expression increased by $10.45 \pm 0.29$-fold after TNF- $\alpha$-stimulation $(p<0.01)$; however, treatment with 6 suppressed it by $4.16 \pm 1.24$-fold $(50 \mu \mathrm{M}, p<0.01)$ and $3.08 \pm 0.53$-fold $(100 \mu \mathrm{M}, p<0.01)$ of the control. IL-6 mRNA expression increased by $5.68 \pm 0.53$-fold $(p<0.05)$ after TNF- $\alpha$ stimulation; however, treatment with 6 suppressed it by $2.60 \pm 0.10$-fold $(50 \mu \mathrm{M}, p<0.05)$ and $2.01 \pm 0.20$-fold $(100 \mu \mathrm{M}, p<0.05)$ of the control. IL-8 mRNA expression increased by $6.24 \pm 0.30$-fold $(p<0.05)$ TNF- $\alpha$ stimulation; however, treatment with 6 suppressed it by $3.83 \pm 0.92$-fold $(50 \mu \mathrm{M})$ and $2.38 \pm 0.38$-fold $(100 \mu \mathrm{M}, p<0.01)$ of the control. As shown in Figure $8 \mathrm{~B}$, the secretion of IL-1 $\beta$ increased to $20.30 \pm 0.27 \mathrm{pg} / \mathrm{mL}(p<0.01)$ after TNF- $\alpha$-stimulation compared with vehicle control $(4.77 \pm 0.04 \mathrm{pg} / \mathrm{mL})$, and treatment with 6 suppressed it to $17.25 \pm 2.61 \mathrm{ng} / \mathrm{mL}(50 \mu \mathrm{M})$ and $7.34 \pm 0.84 \mathrm{pg} / \mathrm{mL}(100 \mu \mathrm{M}, p<0.05)$. The secretion of IL-6 increased to $78.51 \pm 6.32 \mathrm{ng} / \mathrm{mL}(p<0.05)$ after TNF- $\alpha$-stimulation compared with vehicle control (22.51 $\pm 0.63 \mathrm{ng} / \mathrm{mL})$, and treatment with 6 suppressed it to $43.98 \pm 5.47 \mathrm{ng} / \mathrm{mL}$ $(50 \mu \mathrm{M}, p<0.05)$ and $53.29 \pm 5.37 \mathrm{ng} / \mathrm{mL}(100 \mu \mathrm{M}, p<0.05)$. The secretion of IL-8 increased to $53.77 \pm 5.37 \mathrm{ng} / \mathrm{mL}(p<0.05)$ after TNF- $\alpha$-stimulation compared with vehicle control $(15.87 \pm 0.53 \mathrm{ng} / \mathrm{mL})$, and treatment with 6 suppressed it to $35.14 \pm 3.37 \mathrm{ng} / \mathrm{mL}(50 \mu \mathrm{M})$ and $21.66 \pm 5.89 \mathrm{ng} / \mathrm{mL}(100 \mu \mathrm{M}, p<0.05)$.

These results indicate that 3,5,7-trimethoxyflavone (6) suppresses TNF- $\alpha$ stimulationinduced proinflammatory cytokines IL-1 $\beta$, IL-6, and IL-8. Therefore, 3,5,7-trimethoxyflavone (6) has the potential to suppress inflammatory responses in the skin caused by proinflammatory cytokines. 
(A)

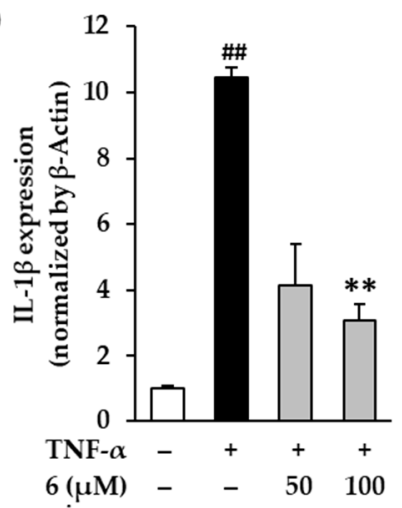

(B)

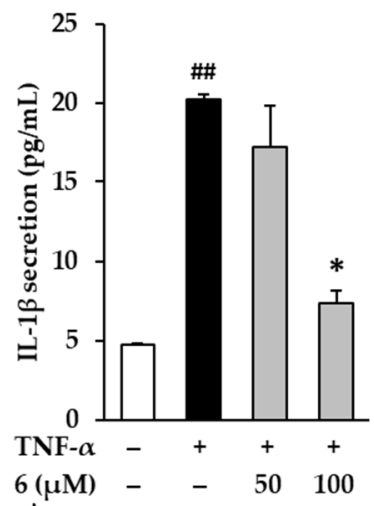

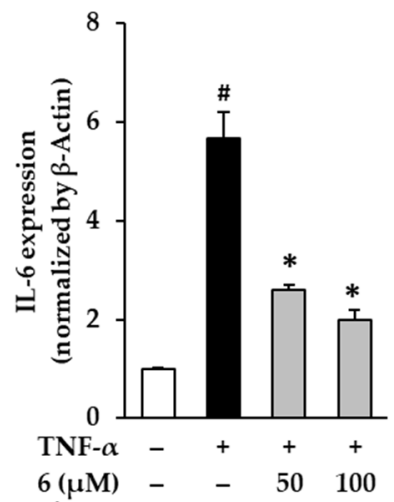
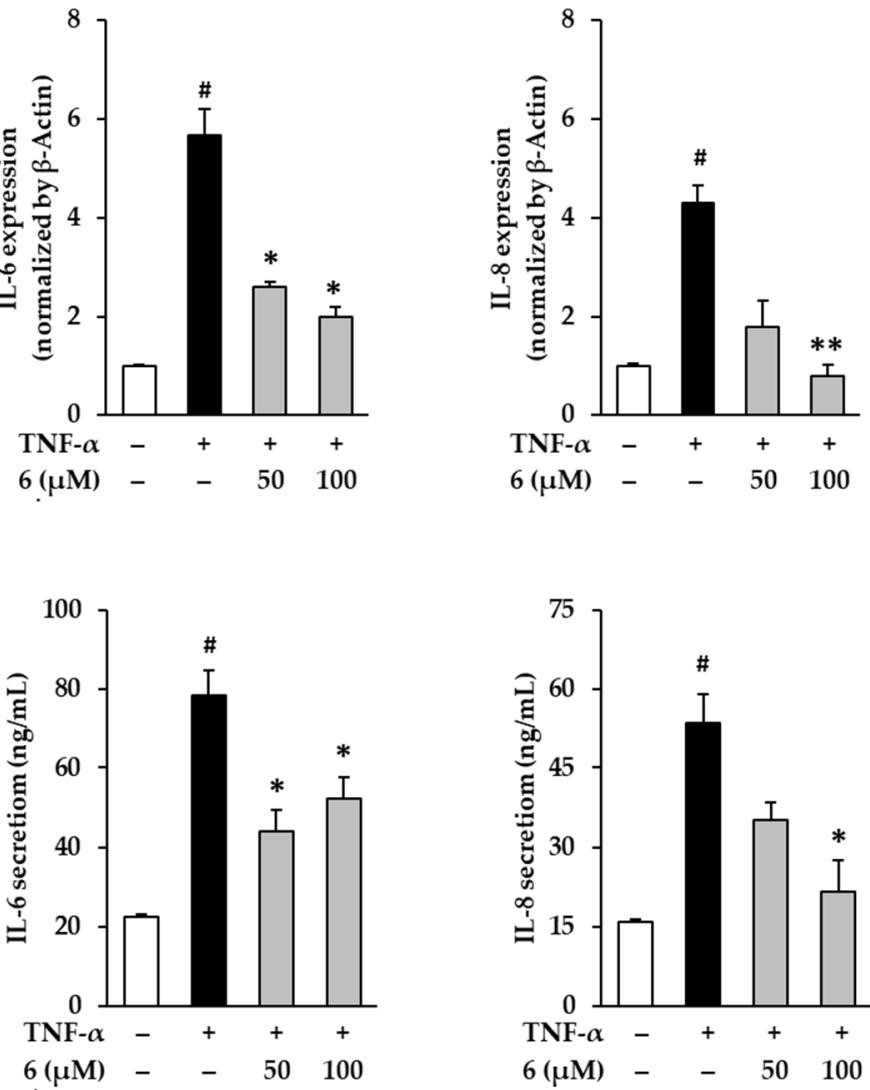

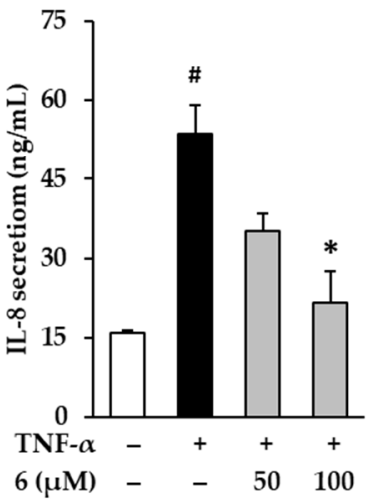

Figure 8. Effects of 3,5,7-trimethoxyflavone (6) on proinflammatory cytokines such as IL-1 $\beta$, IL-6, and IL-8 in normal human dermal fibroblasts (NHDFs) stimulated by TNF- $\alpha$. (A) The mRNA expressions of IL-1 $\beta$, IL-6, and IL- 8 . We seeded NHDFs at $3 \times 10^{5}$ cells/well in 6-well plates, incubated them for $24 \mathrm{~h}$, and then replaced the medium with a serum-free medium to create starvation conditions. After $24 \mathrm{~h}, \mathrm{NHDF}$ were exposed to $20 \mathrm{ng} / \mathrm{mL}$ TNF- $\alpha$ in the presence or absence of 6 for $4 \mathrm{~h}$. The mRNA expressions of IL-1 $\beta$, IL- 6 , and IL- 8 were determined with RT-qPCR. Results of each mRNA expression was presented as percent of the vehicle control. (B) The protein secretion of IL-1 $\beta$, IL-6, and IL-8. We seeded NHDFs at or $2 \times 10^{4}$ cells/well in 48-well plates, and incubated them for $24 \mathrm{~h}$, and then replaced the medium with a serum-free medium to create starvation conditions. After $24 \mathrm{~h}$, cells were treated with 3,5,7-trimethoxyflavone for $24 \mathrm{~h}$. The cells were then exposed to $20 \mathrm{ng} / \mathrm{mL}$ TNF- $\alpha$ for $12 \mathrm{~h}$. The protein secretion of IL-1 $\beta$, IL- 6 , and IL- 8 were determined with an ELISA kit. The experiments were performed in triplicate, and the graphs are represented as mean \pm standard error of the mean (SEM). ${ }^{\#} p<0.05$ and ${ }^{\# \#} p<0.01$ vs. vehicle control. ${ }^{*} p<0.05$ and ${ }^{* *} p<0.01$ vs. TNF- $\alpha$ stimulated control.

\section{Discussion}

The skin is the largest organ of the body. It acts as a barrier against chemical and physical pollutants and protects internal organs. Proteins of extracellular matrix are generated by fibroblasts present in the dermis and are accountable for the elasticity and strength of the skin. Breakdown of ECM from the dermis results in skin aging. There are many types of collagens in the dermal ECM (III, V, VII); however, type I collagen is the most important structural protein. The main cause of aged skin that appears thin, smooth, dry, and inelastic is a decrease in collagen fibers and type I collagen production. In the process of skin aging, the collagenase MMP-1 destroys collagen fibrils. It has been shown that with aging, MMP-1 levels increase and collagen expression in human skin decreases. Furthermore, excessive ECM degradation of the dermis by MMP-1 contributes to inflammation of connective tissue. Therefore, the balance between MMP 1 and type I collagen expression plays an important role in skin aging [55]. 
The skin can age internally by a temporal aging process that affects all body organs or externally because of environmental factors, such as sun exposure and smoking. External and internal skin aging produces inflammatory cytokines, which are closely related to the skin inflammation caused by them. In the process of intrinsic aging and extrinsic aging, various cells of the skin produce the inflammatory cytokine TNF- $\alpha$, which functions as a major regulator of cell metabolism and activity. UV irradiation stimulates cell surface receptors, which are the main contributors of skin aging. Of the ligands for these receptors, TNF- $\alpha$ induces increased MMP expression and decreased collagen expression, leading to ECM disruption. Moreover, TNF- $\alpha$ is considered an important modulator of inflammatory dermatological symptoms and diseases. TNF- $\alpha$ increases pro-inflammatory cytokines such as IL-1 and IL-6, which activate NF- $\mathrm{kB}[25,56,57]$. Therefore, regulation of TNF- $\alpha$ activity can be an attractive strategic method for searching for candidate substances to prevent skin damage and aging $[55,58]$.

In the present research, we studied the effects of methoxyflavones isolated from black ginger (K. parviflora), including 5-hydroxy-7-methoxyflavone (1), 3,7-dimethoxy-5hydroxyflavone (2), 5-hydroxy-3,7,3,4-tetramethoxyflavone (3), 7,4-dimethylapigenin (4), 3,7,4-trimethylkaempferol (5), and 3,5,7-trimethoxyflavone (6) on TNF- $\alpha$-induced damage to normal human dermal fibroblasts (NHDF) with the measurement of MMP-1 and COLIA1 expression. Among the methoxyflavones, 3,5,7-trimethoxyflavone (6) had the intensive ability to protect fibroblasts that were damaged by TNF- $\alpha$, which inhibited MMP-1 secretion. Based on the activities observed, structure-activity relationship (SAR) can be investigated through four groups of the isolated compounds, including (1) compounds 1 and 4, (2) compounds 2 and 6, (3) compounds 3 and 5, and (4) compounds 4 and 5. The SAR analysis suggested that the $3-\mathrm{OCH}_{3}$ and methoxyl groups in B-ring are not associated with the protective effects based on the activities of $1 / 4,3 / 5$, and $4 / 5$. In contrast, the $5-\mathrm{OCH}_{3}$ moiety played a critical role in the activity, considering that compound 6 with $5-\mathrm{OCH}_{3}$ showed the potent activity, whereas compound 2 with $5-\mathrm{OH}$ was inactive.

COX-2, IL-1, and IL-6 are pro-inflammatory mediators that play a major role in causing skin aging and inflammatory skin symptoms. In skin aging, COX-2 acts as a mediator for the biosynthesis of prostaglandin E2, which contributes to the production of MMPs. IL-1 and IL-6 are regulators that contribute to skin wrinkle formation, including inhibition of collagen biosynthesis [59]. Luteolin, a flavonoid isolated and reported from various natural products, suppresses ROS and pro-inflammatory mediators and promotes photoaging of the epidermis and dermis to reduce IL-6, IL-22, IL-17, and COX-2 [46]. Similarly, 3,5,7trimethoxyflavone (6) significantly inhibits TNF- $\alpha$-induced expression of IL- $1 \beta$, IL-6, and COX-2 and is expected to have a protective effect on skin damage based on inhibition of inflammation-related reactions.

Oxidative stress is also an important factor related to skin aging. Reactive oxygen species generated by intrinsic (chronic aging) and total permeable aging (optical) stimulate MMP expression, suppress growth factor-beta signaling, suppress collagen degradation, and trigger collagen fibrous biosynthesis [60]. Therefore, development of skin antioxidants with natural products is one of the major strategies of skincare product development in the cosmetics industry [61]. According to a recent study by Li et al., orange lowtemperature crimping oil has a high content of polymethoxyflavones and was effective in preventing UVB-induced oxidative damage in mouse skin [62]. Similarly, in this study, 3,5,7trimethoxyflavone (6) had the effect of suppressing the reactive oxygen species produced by stimulation with TNF- $\alpha$ in NHDFs. The position and number of methoxy groups in the polymethoxyflavone structure related to the antioxidant properties, suggest a relevance for these pharmacological effects.

MAPK plays a central role in controlling skin damage in combination with two downstream pathways associated with oxidative stress and inflammatory responses, AP-1 and NF- $\mathrm{KB}[62,63]$. In addition, activation of MAPK induces phosphorylation and rearrangement of NF- $\mathrm{B}$, producing MMP-1 and inflammatory cytokines [62,64]. Therefore, retrograde movement of this pathway plays an important role in delaying skin aging. 
Previous reports have shown that treatment with MAPK inhibitors reversed the photoaging process $[19,64]$. NHDFs treated with 3,5,7-trimethoxyflavone (6) showed diminished phosphorylation of MAPK. This resulted in inhibition of MMP-1 production and collagen degradation. In this study, 3,5,7-trimethoxyflavone (6) has also been shown as a potential MAPK, Akt, and COX-2 inhibitor. NHDFs treated with 3,5,7-trimethoxyflavone (6) showed reduced phosphorylation of MAPK, reduced phosphorylation of Akt, and reduced COX-2.

In summary, among the methoxyflavones isolated from black ginger (K. parviflora), 3,5,7-trimethoxyflavone (6) has potent preventive effect in TNF- $\alpha$-induced injury to HDFs by suppressing MMP-1 expression and recovery COLIA1 expression. In TNF- $\alpha$-stimulated $\mathrm{HDF}$, the skin protection mechanism of 3,5,7-trimethoxyflavone (6) involves the reduction of reactive oxygen species and anti-inflammatory mediators, including COX-2, IL-1, IL-6, and IL-8 production, through the inhibition of oxidative stress and inflammatory response. Moreover, 3,5,7-trimethoxyflavone (6) alleviates the phosphorylation of MAPK and Akt, which inhibits MMP-1 production and collagen fiber degradation.

However, this study had some limitations. For example, the potential of 3,5,7trimethoxyflavone (6) to prevent skin aging has been studied only in HDFs. To completely understand the anti-aging effect of 3,5,7-trimethoxyflavone (6), research needs to be extended to many different cell lines such as melanocytes, keratinocytes, and organic 3D skin models.

Our previous study has shown that 5,7,4'trimethoxyflavone is effective at low concentrations of 6.25 and $12.5 \mu \mathrm{M}$ [63]. On Because 3,5,7-trimethoxyflavone (6) compound 6 is effective at 50 or more, the question of weak activity may be raised. However, skin improvers directly penetrate the skin to show their effects. Therefore, the active compound must penetrate the skin barrier without causing skin irritation. Recent studies have reported that the microemulsion formulation quercetin increases skin penetration [64]. Therefore, it is believed that additional studies such as topical and transdermal delivery are needed to determine if a physiological approach is possible.

\section{Conclusions}

The results of this study indicate that 3,5,7-trimethoxyflavone (6) isolated from $K$. parviflora has inhibitory effects on TNF- $\alpha$-induced MMP-1 in NHDFs. It was found that 3,5,7-trimethoxyflavone inhibited TNF- $\alpha$-induced ROS, which plays a key role in the inflammatory response and ECM degradation that occurs during skin damage, such as skin aging and various cutaneous lesions. The changes by which 3,5,7-trimethoxyflavone (6) reduces TNF- $\alpha$-stimulated responses in NHDFs are correlated with the suppression of Akt, COX-2, MAPK activation, and induction of HO-1. Moreover, 3,5,7-trimethoxyflavone reduced the expression of proinflammatory cytokine mediators induced by TNF- $\alpha$ stimulation, including IL-1 $\beta$, IL-6, and IL-8. These findings provide evidence that 3,5,7-trimethoxyflavones may protect against skin damage caused by accumulation of oxidative stress. Additional experiments are required to fully understand the mechanism of 3,5,7-trimethoxyflavone activity; however, it is a potential substance for preventing skin damage, including skin aging and various skin lesions.

Supplementary Materials: The following are available online at https: / www.mdpi.com/article / 10.3390/antiox11020425/s1, Figure S1: ${ }^{1} \mathrm{H}-\mathrm{NMR}$ spectrum of compound 1 (in $\mathrm{CDCl}_{3}$ ), Figure S2: ${ }^{1} \mathrm{H}-\mathrm{NMR}$ spectrum of compound 2 (in $\mathrm{CDCl}_{3}$ ), Figure S3: ${ }^{1} \mathrm{H}-\mathrm{NMR}$ spectrum of compound 3 (in $\mathrm{CDCl}_{3}$ ), Figure S4: ${ }^{1} \mathrm{H}-\mathrm{NMR}$ spectrum of compound 4 (in $\mathrm{CDCl}_{3}$ ), Figure S5: ${ }^{1} \mathrm{H}-\mathrm{NMR}$ spectrum of compound 5 (in $\mathrm{CDCl}_{3}$ ), Figure S6: ${ }^{1} \mathrm{H}-\mathrm{NMR}$ spectrum of compound 6 (in $\mathrm{CDCl}_{3}$ ).

Author Contributions: Conceptualization, K.H.K. and K.S.K.; validation, S.L. and T.J.; formal analysis, S.L.; writing—original draft preparation, S.L. and T.J.; writing—review and editing, S.L.; project administration, K.H.K. and K.S.K. All authors have read and agreed to the published version of the manuscript. 
Funding: This research was supported by the Ministry of Trade, Industry \& Energy (MOTIE), Korea Institute for Advancement of Technology (KIAT), through the Program for Smart Specialization Infrastructure Construction (p0014630) and the National Research Foundation of Korea (NRF), the Ministry of Education, through Basic Science Research Program (2019R1C1C100791413). This work was supported by National Research Foundation of Korea (NRF) grants funded by the Korean government (MSIT) (grant numbers 2019R1A5A2027340 and 2021R1A2C2007937). This study was also funded by Gachon University with grant number GC-202103600001.

Institutional Review Board Statement: Not applicable.

Informed Consent Statement: Not applicable.

Data Availability Statement: Data is contained within the article and supplementary materials.

Conflicts of Interest: The authors declare no conflict of interest.

\section{References}

1. James, W.D.; Elston, D.; Berger, T. Andrew's Diseases of the Skin E-Book: Clinical Dermatology, 11th ed.; Elsevier Health Sciences: Amsterdam, The Netherlands, 2011; pp. 1-11.

2. Poljšak, B.; Dahmane, R.G.; Godić, A. Intrinsic skin aging: The role of oxidative stress. Acta Dermatovenerol. Alp. Pannon. Adriat. 2012, 21, 33-36.

3. Puizina-Ivic, N. Skin aging. Acta Dermatovenerol. Alp. Panon. Adriat. 2008, 17, 47.

4. Farage, M.; Miller, K.; Elsner, P.; Maibach, H. Intrinsic and extrinsic factors in skin ageing: A review. Int. J. Cosmeti. Sci. 2008, 30, 87-95. [CrossRef] [PubMed]

5. Baumann, L. Skin ageing and its treatment. J. Pathol. 2007, 211, 241-251. [CrossRef]

6. Pillai, S.; Oresajo, C.; Hayward, J. Ultraviolet radiation and skin aging: Roles of reactive oxygen species, inflammation and protease activation, and strategies for prevention of inflammation-induced matrix degradation-A review. Int. J. Cosmet. Sci. 2005, 27, 17-34. [CrossRef]

7. Nichols, J.A.; Katiyar, S.K. Skin photoprotection by natural polyphenols: Anti-inflammatory, antioxidant and DNA repair mechanisms. Arch. Dermatol. Res. 2010, 302, 71-83. [CrossRef]

8. Kohl, E.; Steinbauer, J.; Landthaler, M.; Szeimies, R.M. Skin ageing. J. Eur. Acad. Dermatol. Venereol. 2011, 25, 873-884. [CrossRef]

9. Yaar, M.; Gilchrest, B.A. Photoageing: Mechanism, prevention and therapy. Br. J. Dermatol. 2007, 157, 874-887. [CrossRef]

10. Anderson, A.; Bowman, A.; Boulton, S.J.; Manning, P.; Birch-Machin, M.A. A role for human mitochondrial complex II in the production of reactive oxygen species in human skin. Redox Bio. 2014, 2, 1016-1022. [CrossRef]

11. Alfadda, A.A.; Sallam, R.M. Reactive oxygen species in health and disease. J. Biomed. Biotechnol. 2012, 2012, 936486. [CrossRef]

12. Nita, M.; Grzybowski, A. The role of the reactive oxygen species and oxidative stress in the pathomechanism of the age-related ocular diseases and other pathologies of the anterior and posterior eye segments in adults. Oxid. Med. Cell. Longev. 2016, 2016, 3164734. [CrossRef] [PubMed]

13. Zorov, D.B.; Juhaszova, M.; Sollott, S.J. Mitochondrial reactive oxygen species (ROS) and ROS-induced ROS release. Physiol. Rev. 2014, 94, 909-950. [CrossRef] [PubMed]

14. Ågren, M.S.; Schnabel, R.; Christensen, L.H.; Mirastschijski, U. Tumor necrosis factor- $\alpha$-accelerated degradation of type I collagen in human skin is associated with elevated matrix metalloproteinase (MMP)-1 and MMP-3 ex vivo. Eur. J. Cell Biol. 2015, $94,12-21$. [CrossRef] [PubMed]

15. Kammeyer, A.; Luiten, R. Oxidation events and skin aging. Ageing Res. Rev. 2015, 21, 16-29. [CrossRef]

16. Svobodova, A.; Walterova, D.; Vostalova, J. Ultraviolet light induced alteration to the skin. Biomed. Pap. Med. Fac. Univ. Palacky Olomouc 2006, 150, 25. [CrossRef]

17. Athar, M.; An, K.P.; Morel, K.D.; Kim, A.L.; Aszterbaum, M.; Longley, J.; Epstein, E.H., Jr.; Bickers, D.R. Ultraviolet B (UVB)induced cox-2 expression in murine skin: An immunohistochemical study. Biochem. Biophys. Res. Commun. 2001, 280, 1042-1047. [CrossRef]

18. Clydesdale, G.J.; Dandie, G.W.; Muller, H.K. Ultraviolet light induced injury: Immunological and inflammatory effects. Immunol. Cell Biol. 2001, 79, 547-568. [CrossRef]

19. Tanaka, K.; Asamitsu, K.; Uranishi, H.; Iddamalgoda, A.; Ito, K.; Kojima, H.; Okamoto, T. Protecting skin photoaging by NF-кB inhibitor. Curr. Drug Metab. 2010, 11, 431-435. [CrossRef]

20. Lee, B.-C.; Lee, S.Y.; Lee, H.J.; Sim, G.-S.; Kim, J.-H.; Kim, J.-H.; Cho, Y.-H.; Lee, D.-H.; Pyo, H.-B.; Choe, T.-B. Anti-oxidative and photo-protective effects of coumarins isolated fromFraxinus chinensis. Arch. Pharm. Res. 2007, 30, 1293. [CrossRef]

21. Varani, J.; Spearman, D.; Perone, P.; Fligiel, S.E.; Datta, S.C.; Wang, Z.Q.; Shao, Y.; Kang, S.; Fisher, G.J.; Voorhees, J.J. Inhibition of type I procollagen synthesis by damaged collagen in photoaged skin and by collagenase-degraded collagen in vitro. Am. J. Pathol. 2001, 158, 931-942. [CrossRef]

22. Sin, B.Y.; Kim, H.P. Inhibition of collagenase by naturally-occurring flavonoids. Arch. Pharm. Res. 2005, 28, 1152-1155. [CrossRef] 
23. Bae, J.-Y.; Choi, J.-S.; Choi, Y.-J.; Shin, S.-Y.; Kang, S.-W.; Han, S.J.; Kang, Y.-H. (-) Epigallocatechin gallate hampers collagen destruction and collagenase activation in ultraviolet-B-irradiated human dermal fibroblasts: Involvement of mitogen-activated protein kinase. Food Chem. Toxicol. 2008, 46, 1298-1307. [CrossRef] [PubMed]

24. Borg, M.; Brincat, S.; Camilleri, G.; Schembri-Wismayer, P.; Brincat, M.; Calleja-Agius, J. The role of cytokines in skin aging Climacteric 2013, 16, 514-521. [CrossRef] [PubMed]

25. Brotas, A.M.; Cunha, J.M.T.; Lago, E.H.J.; Machado, C.C.N.; Carneiro, S.C.D.S. Tumor necrosis factor-alpha and the cytokine network in psoriasis. An. Bras. Dermatol. 2012, 87, 673-683. [CrossRef] [PubMed]

26. Toda, K.; Hitoe, S.; Takeda, S.; Shimoda, H. Black ginger extract increases physical fitness performance and muscular endurance by improving inflammation and energy metabolism. Heliyon 2016, 2, e00115. [CrossRef]

27. Saokaew, S.; Wilairat, P.; Raktanyakan, P.; Dilokthornsakul, P.; Dhippayom, T.; Kongkaew, C.; Sruamsiri, R.; Chuthaputti, A.; Chaiyakunapruk, N. Clinical effects of Krachaidum (Kaempferia parviflora): A systematic review. Evid. Based Complementary Altern. Med. 2017, 22, 413-428. [CrossRef] [PubMed]

28. Chen, D.; Li, H.; Li, W.; Feng, S.; Deng, D. Kaempferia parviflora and its methoxyflavones: Chemistry and biological activities. Evid. Based Complementary Altern. Med. 2018, 2018, 4057456. [CrossRef] [PubMed]

29. Okabe, Y.; Shimada, T.; Horikawa, T.; Kinoshita, K.; Koyama, K.; Ichinose, K.; Aburada, M.; Takahashi, K. Suppression of adipocyte hypertrophy by polymethoxyflavonoids isolated from Kaempferia parviflora. Phytomedicine 2014, 21, 800-806. [CrossRef]

30. Azuma, T.; Tanaka, Y.; Kikuzaki, H. Phenolic glycosides from Kaempferia parviflora. Phytochemistry 2008, 69, 2743-2748. [CrossRef]

31. Wu, L.; Liu, H.; Li, L.; Liu, H.; Yang, K.; Liu, Z.; Huang, H. 5, 7, 3' , 4'-Tetramethoxyflavone exhibits chondroprotective activity by targeting $\beta$-catenin signaling in vivo and in vitro. Biochem. Biophys. Res. Commun. 2014, 452, 682-688. [CrossRef]

32. Yenjai, C.; Prasanphen, K.; Daodee, S.; Wongpanich, V.; Kittakoop, P. Bioactive flavonoids from Kaempferia parviflora. Fitoterapia 2004, 75, 89-92. [CrossRef] [PubMed]

33. Yu, J.S.; Park, M.; Pang, C.; Rashan, L.; Jung, W.H.; Kim, K.H. Antifungal phenols from Woodfordia uniflora collected in Oman. J. Nat. Prod. 2020, 83, 2261-2268. [CrossRef] [PubMed]

34. Ha, J.W.; Kim, J.; Kim, H.; Jang, W.; Kim, K.H. Mushrooms: An important source of natural bioactive compounds. Nat. Prod. Sci. 2020, 26, 118-131.

35. Lee, S.; Ryoo, R.; Choi, J.H.; Kim, J.-H.; Kim, S.-H.; Kim, K.H. Trichothecene and tremulane sesquiterpenes from a hallucinogenic mushroom Gymnopilus junonius and their cytotoxicity. Arch. Pharm. Res. 2020, 43, 214-223. [CrossRef] [PubMed]

36. Lee, S.R.; Kang, H.; Yoo, M.J.; Yu, J.S.; Lee, S.; Yi, S.A.; Beemelmanns, C.; Lee, J.; Kim, K.H. Anti-adipogenic pregnane steroid from a Hydractinia-associated fungus, Cladosporium sphaerospermum SW67. Nat. Prod. Sci. 2020, 26, 230-235.

37. Lephart, E.D. Equol's anti-aging effects protect against environmental assaults by increasing skin antioxidant defense and ECM proteins while decreasing oxidative stress and inflammation. Cosmetics 2018, 5, 16. [CrossRef]

38. Petruk, G.; Del Giudice, R.; Rigano, M.M.; Monti, D.M. Antioxidants from plants protect against skin photoaging. Oxid. Med. Cell. Longev. 2018, 2018, 1454936. [CrossRef]

39. Chen, M.; Huang, J.; Yang, X.; Liu, B.; Zhang, W.; Huang, L.; Deng, F.; Ma, J.; Bai, Y.; Lu, R. Serum starvation induced cell cycle synchronization facilitates human somatic cells reprogramming. PLoS ONE 2012, 7, e28203. [CrossRef]

40. Lee, S.; Hoang, G.D.; Kim, D.; Song, H.S.; Choi, S.; Lee, D.; Kang, K.S. Efficacy of alpinumisoflavone isolated from maclura tricuspidata fruit in tumor necrosis factor- $\alpha$-induced damage of human dermal fibroblasts. Antioxidants 2021, 10, 514. [CrossRef]

41. Dao, T.T.; Chi, Y.S.; Kim, J.; Kim, H.P.; Kim, S.; Park, H. Synthesis and PGE 2 inhibitory activity of 5, 7-dihydroxyflavones and their o-methylated flavone analogs. Arch. Pharm. Res. 2003, 26, 345-350. [CrossRef]

42. Chou, T.-H.; Chen, J.-J.; Lee, S.-J.; Chiang, M.Y.; Yang, C.-W.; Chen, I.-S. Cytotoxic flavonoids from the leaves of Cryptocarya chinensis. J. Nat. Prod. 2010, 73, 1470-1475. [CrossRef] [PubMed]

43. Nguyen, T.K.P.; Nguyen, K.P.P.; Kamounah, F.S.; Zhang, W.; Hansen, P.E. NMR of a series of novel hydroxyflavothiones. Magn. Reson. Chem. 2009, 47, 1043-1054. [CrossRef] [PubMed]

44. Jang, D.S.; Han, A.-R.; Park, G.; Jhon, G.-J.; Seo, E.-K. Flavonoids and aromatic compounds from the rhizomes of Zingiber zerumbet. Arch. Pharm. Res. 2004, 27, 386-389. [CrossRef] [PubMed]

45. Sookkongwaree, K.; Geitmann, M.; Roengsumran, S.; Petsom, A.; Danielson, U.H. Inhibition of viral proteases by Zingiberaceae extracts and flavones isolated from Kaempferia parviflora. Int. J. Pharm. Sci. Res. 2006, 61, 717-721.

46. Gendrisch, F.; Esser, P.R.; Schempp, C.M.; Wölfle, U. Luteolin as a modulator of skin aging and inflammation. Biofactors 2021, 47, 170-180. [CrossRef]

47. Seo, S.-H.; Jeong, G.-S. Fisetin inhibits TNF- $\alpha$-induced inflammatory action and hydrogen peroxide-induced oxidative damage in human keratinocyte HaCaT cells through PI3K/AKT/Nrf-2-mediated heme oxygenase-1 expression. Int. Immunopharmacol. 2015, 29, 246-253. [CrossRef]

48. Kimura, S.; Warabi, E.; Yanagawa, T.; Ma, D.; Itoh, K.; Ishii, Y.; Kawachi, Y.; Ishii, T. Essential role of Nrf2 in keratinocyte protection from UVA by quercetin. Biochem. Biophys. Res. Commun. 2009, 387, 109-114. [CrossRef]

49. Uitto, J. The role of elastin and collagen in cutaneous aging: Intrinsic aging versus photoexposure. J. Drugs Dermatol. 2008, 7, s12.

50. Brenneisen, P.; Sies, H.; Scharffetter-Kochanek, K. Ultraviolet-B irradiation and matrix metalloproteinases: From induction via signaling to initial events. Ann. N. Y. Acad. Sci. 2002, 973, 31-43. [CrossRef] 
51. Inomata, S.; Takada, K.; Tsunenaga, M.; Fukuda, M.; Matsunaga, Y.; Amano, S.; Kobayashi, K.; Nishiyama, T.; Kohno, Y. Possible involvement of gelatinases in basement membrane damage and wrinkle formation in chronically ultraviolet B-exposed hairless mouse. J. Investig. Dermatol. 2003, 120, 128-134. [CrossRef]

52. Bornstein, P. The biosynthesis of collagen. Annu. Rev. Biochem. 1974, 43, 567-603. [CrossRef] [PubMed]

53. Tu, Y.; Quan, T. Oxidative stress and human skin connective tissue aging. Cosmetics 2016, 3, 28. [CrossRef]

54. Chen, Y.; Lyga, J. Brain-skin connection: Stress, inflammation and skin aging. Inflamm. Allergy Drug Targets. 2014, 13, 177-190. [CrossRef]

55. Choi, J.W.; Lee, J.; Park, Y.I. 7, 8-Dihydroxyflavone attenuates TNF- $\alpha$-induced skin aging in Hs68 human dermal fibroblast cells via down-regulation of the MAPKs/Akt signaling pathways. Biomed. Pharmacother. 2017, 95, 1580-1587. [CrossRef] [PubMed]

56. Meephansan, J.; Subpayasarn, U.; Komine, M.; Ohtsuki, M. Pathogenic Role of Cytokines and Effect of Their Inhibition in Psoriasis; IntechOpen: Rijeka, Croatia, 2017; pp. 41-57.

57. Goldminz, A.; Au, S.; Kim, N.; Gottlieb, A.; Lizzul, P. NF-кB: An essential transcription factor in psoriasis. J. Dermatol. Sci. 2013, 69, 89-94. [CrossRef] [PubMed]

58. Na, J.; Bak, D.H.; Im, S.I.; Choi, H.; Hwang, J.H.; Kong, S.Y.; No, Y.A.; Lee, Y.; Kim, B.J. Anti-apoptotic effects of glycosaminoglycans via inhibition of ERK/AP-1 signaling in TNF- $\alpha$-stimulated human dermal fibroblasts. Int. J. Mol. Med. 2018, 41, 3090-3098. [CrossRef]

59. Shim, J.H. Prostaglandin $\mathrm{E}_{2}$ induces skin aging via E-prostanoid 1 in normal human dermal fibroblasts. Int. J. Mol. Med. 2019, 20, 5555. [CrossRef]

60. Shin, J.-W.; Kwon, S.-H.; Choi, J.-Y.; Na, J.-I.; Huh, C.-H.; Choi, H.-R.; Park, K.-C. Molecular mechanisms of dermal aging and antiaging approaches. Int. J. Mol. Med. 2019, 20, 2126. [CrossRef]

61. Ganceviciene, R.; Liakou, A.I.; Theodoridis, A.; Makrantonaki, E.; Zouboulis, C.C. Skin anti-aging strategies. Derm. Endocrinol. 2012, 4, 308-319. [CrossRef]

62. Li, G.; Tan, F.; Zhang, Q.; Tan, A.; Cheng, Y.; Zhou, Q.; Liu, M.; Tan, X.; Huang, L.; Rouseff, R. Protective effects of polymethoxyflavone-rich cold-pressed orange peel oil against ultraviolet B-induced photoaging on mouse skin. J. Funct. Foods 2020, 67, 103834. [CrossRef]

63. Phung, H.M.; Lee, S.; Hong, S.; Lee, S.; Jung, K.; Kang, K.S. Protective Effect of Polymethoxyflavones Isolated from Kaempferia parviflora against TNF- $\alpha$-Induced Human Dermal Fibroblast Damage. Antioxidants 2021, 10, 1609. [CrossRef] [PubMed]

64. Vicentini, F.T.; Simi, T.R.; Del Ciampo, J.O.; Wolga, N.O.; Pitol, D.L.; Iyomasa, M.M.; Bentley, M.V.L.; Fonseca, M.J. Quercetin in $\mathrm{w} / \mathrm{o}$ microemulsion: In vitro and in vivo skin penetration and efficacy against UVB-induced skin damages evaluated in vivo. Eur. J. Pharm. Biopharm. 2008, 69, 948-957. [CrossRef] [PubMed] 